\title{
Essays on Globalization and Economic Development
}

\author{
A DISSERTATION \\ SUBMITTED TO THE FACULTY OF THE GRADUATE \\ SCHOOL \\ OF THE UNIVERSITY OF MINNESOTA \\ BY \\ Nan Xu \\ IN PARTIAL FULFILLMENT OF THE REQUIREMENTS \\ FOR THE DEGREE OF \\ Doctor of Philosophy
}

Timothy J. Kehoe, Adviser

Fabrizio Perri, Co-Adviser

August, 2011 
(C) Nan Xu 2011

\section{ALL RIGHTS RESERVED}




\section{Acknowledgements}

I would like to thank my advisers Tim Kehoe and Fabrizio Perri for their continued guidance and support through the project. They brought me to the field of international economics and taught me how to do serious economic research. I would also like to extend my thanks to Tom Holmes and Terry Roe for serving on my exam committee and providing helpful comments and suggestions during the early period of this project.

I would like to thank Pu Chen, Yenan Hou, Jing Fang, and Dingming Liu for their helpful discussions. Many thanks also go to the participants of Trade and Development Workshop at Minnesota.

Finally, I would like to express my deepest gratitude to my parents who make it possible. I also thank my wife Bai Jieru for making it happen. 


\section{Dedication}

To Bai Jieru, for her unending love and support 


\begin{abstract}
This thesis investigates the role of globalization in economic development. This thesis consists of three essays.

The first essay studies the role of resource reallocation and globalization in economic development for China. Recent literature on economic growth emphasizes the misallocation of resource at the micro level could reduce TFP at the macro level. Both structural transformation and globalization in China contribute to correct the misallocation of resources in China. Hence they could account for the remarkable growth experience of China. This paper develops a neoclassical growth model that emphasizes the role of structural transformation and international trade to account for the growth experience of China. I calibrate the model to match the data of China and show that the process of structural transformation in an open economy can generate growth rate of GDP comparable to those observed in China in the period 1991-2004.

The second essay is a theoretical study of international trade and economic growth. I build an endogenous growth model with heterogeneous firms. I find that trade liberalization can help reallocate resources to innovation and therefore promotes economic growth.

The third essay reviews the literature of structural change and its implications for economic development. Developing countries started to develop from reallocating labor in agriculture to industrial production. This essay reviews
\end{abstract}


the two main mechanism to generate structural change in standard models of economic growth. Then I review the literature on the role of structural change in studying various issues in economic development. 


\section{Contents}

Acknowledgements i

Dedication ii

Abstract iii

List of Tables viii

List of Figures ix

\begin{tabular}{lll}
\hline & Introduction & 1
\end{tabular}

2 Reallocation, Globalization, and Economic Growth in China 5

$2.1 \quad$ Introduction . . . . . . . . . . . . . . . . . . 5

2.1 .1 Related Literature . . . . . . . . . . . . . . . . . . . 10

2.2 Empirical Evidence: The China Miracle . . . . . . . . . . . . . . 13

2.3 The Model . . . . . . . . . . . . . . . . . . . . . . . . . . . . . 15

2.3 .1 Household $\ldots \ldots \ldots$. . . . . . . . . . . . . . . . . . . . . . 16

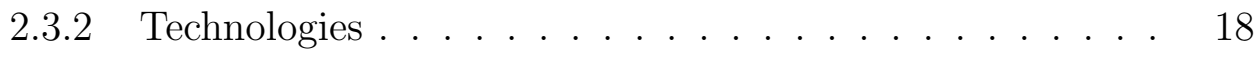


$2.3 .3 \quad$ Equilibrium $\ldots \ldots \ldots \ldots \ldots$

2.3 .4 Characterization . . . . . . . . . . . . 22

2.4 Calibration . . . . . . . . . . . . . . . . . . . 26

2.5 Results $\ldots \ldots \ldots \ldots \ldots \ldots$

2.6 Concluding Remarks $\ldots \ldots \ldots \ldots \ldots$

3 When Schumpeter meets Melitz: An Endogenous Growth Model

with Heterogeneous Firms 39

3.1 Introduction . . . . . . . . . . . . . . . . . . . . . . . . . . . . . . 39

3.2 The Model . . . . . . . . . . . . . . . . . . . . . . . . . . . 45

3.2 .1 Consumer . . . . . . . . . . . . . . . . 45

3.2 .2 Producers . . . . . . . . . . . . . . . . . . 46

$3.2 .3 \quad$ Innovations and Export Decisions $\ldots \ldots \ldots \ldots . . .47$

3.2 .4 Creative Destruction and Value of Firms . . . . . . . . 48

3.2 .5 Labor Market . . . . . . . . . . . . . . . . . . . . . . . 49

3.3 Steady State Equilibrium $\ldots \ldots \ldots \ldots$

3.4 The Impact of Trade . . . . . . . . . . . . . . . . . . . . . . 53

$3.5 \quad$ Concluding Remarks $\ldots \ldots \ldots \ldots \ldots$

4 Structural Change and Economic Development: A Revisit 59

4.1 Introduction . . . . . . . . . . . . . . . . . . . . . . . 59

4.2 An Illustrative Model . . . . . . . . . . . . . . . . . . . . . . . . 61

4.2 .1 The Model . . . . . . . . . . . . . . . . . . . . . . . . . 62

$4.3 \quad$ Structural Change: Demand Side Analysis . . . . . . . . . . . 64 
4.3 .1 The Model . . . . . . . . . . . . . . . . . . . . . . . 65

4.3 .2 The $\operatorname{Setup} \ldots \ldots \ldots \ldots \ldots$

4.3 .3 Equilibrium . . . . . . . . . . . . . . . 66

4.4 Dynamic Models . . . . . . . . . . . . . . . . . . . . . . 68

$4.4 .1 \quad$ A Dynamic three-sector Model. . . . . . . . . . . . . 68

$4.4 .2 \quad$ A Dynamic Multisector Model . . . . . . . . . . . 70

4.5 Implications for Economic Development. . . . . . . . . . . 72

4.6 Globalization and Structural Change . . . . . . . . . . 75

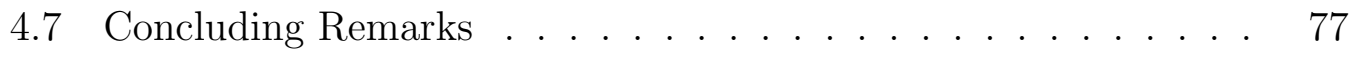

\begin{tabular}{ll}
\hline References & 79
\end{tabular}

\begin{tabular}{|l|l|}
\hline Appendix A. Appendix to Chapter & 85
\end{tabular}

A.1 Representative Household Problem . . . . . . . . . . . . . 85

A.2 Proof of Proposition $1 \ldots \ldots \ldots \ldots$

\begin{tabular}{|ll|r|}
\hline Appendix B. Appendix to Chapter & 88 \\
\hline
\end{tabular}

B.1 Derivation of Aggregate Consumption . . . . . . . . . . . 88

B.2 $\quad$ Derivation of $(26)$. . . . . . . . . . . . . . . . . . . . . 89

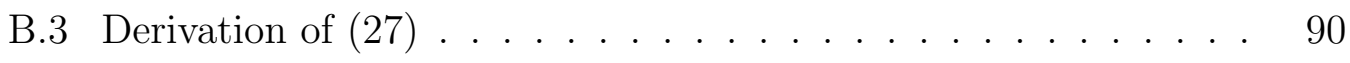

vii 


\section{List of Tables}

2.1 Calibration of Parameters. . . . . . . . . . . . . . 26

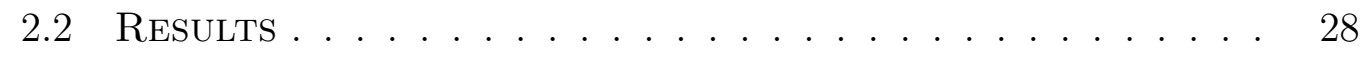




\section{List of Figures}

2.1 REAL GDP PER CAPITA OF CHINA: 1970-2009 . . . . . . . 6

2.2 RuRal Population as a PERCEnTage of Total PopulaTION OF CHINA: 1970-2009 . . . . . . . . . . . . . . . 14

2.3 VAlue ADDED AS A PERCENTAGE OF GDP IN AGRICULTURE (SOURCE: WorlD BANK World Development Indicators)] . . . 15

2.4 International TRADE AS A PERCENTAGE OF GDP (SOURCE: WORLD BANK World Development Indicators) $\ldots$. . . . . . . 16

2.5 LABOR AlLOCATION IN AGRICULTURAL SECTOR (OPEN ECONOMY SETUP): 1991-2004 … . . . . . . . . . . . . . 29

2.6 REAL GDP (OPEN ECONOMY SETUP): 1991-2004 . . . . . . . 30

2.7 LabOr Allocation In AgRicultural SeCtor (ClOSED ECONOMY SETUP): $1991-2004 \ldots \ldots \ldots \ldots$

2.8 REAL GDP (CLOSED ECONOMY): 1991-2004 . . . . . . . . 33

2.9 LabOr Allocation In AGricultural SeCtor (HomOthetic Preferences): 1991-2004 … . . . . . . . . 34

2.10 Real GDP (Homothetic PrefERences): 1991-2004 . . . 35 
2.11 Labor Allocation in Agricultural SeCtor (No Import OF InTERMEDIATE GoOd): 1991-2004 . . . . . . . . . . . . . 36

2.12 ReAl GDP (No Import of Intermediate GoOd): 1991$2004 \ldots \ldots \ldots \ldots \ldots \ldots$ 


\section{Chapter 1}

\section{Introduction}

The world is becoming flat. We have seen a spectacular increase in international trade and foreign direct investment in recent years. Many countries engage in the global production sharing. Varian (2007) discusses an interesting example of global production sharing for Apple's iPod. iPod is designed in the U.S. and assembled in China. However, most of its value comes from parts made in other countries. He cites an interesting study Linden, Kraemer, and Dedrick (2009) to illustrate the complexity of the global economy.

The retail value of the 30-gigabyte video iPod that the authors examined was $\$ 299$. The most expensive component in it was the hard drive, which was manufactured by Toshiba and costs about $\$ 73$. The next most costly components were the display module (about $\$ 20$ ), the video/multimedia processor chip (\$8) and the controller chip (\$5). They estimated that the final assembly, done in China, cost 
only about $\$ 4$ a unit.

The labor division at the global level gives developing countries an opportunity to further explore their comparative advantage of labor abundance. The processing trade is pervasive in China now and contribute to a significant part of the trade in China. Globalization changes the production pattern in China and helps Chinese economy develop. China imports a variety of intermediate goods from abroad and assemble them into the final product in China later ships final manufacturing goods to the rest of the world.

This dissertation consists of three essays that attempt to shed light on how globalization impacts the economic growth in general and specially for the Chinese economy.

Chapter 2 starts from the empirical facts of the China Miracle. I first review some empirical facts of the Chinese economy since China opens its economy to the world in 1978. I construct a neoclassical growth model to reconcile these facts. Recent growth literature emphasizes the misallocation of resource at the micro level could reduce TFP at the macro level. Both structural transformation and globalization in China contribute to correct the misallocation of resources in China. Hence they could account for the remarkable growth experience of China. In this essay, I develops a growth model that emphasizes the role of structural transformation and international trade to account for the growth experience of China. Structural transformation releases a large population living in agricultural sector and makes China have comparative advantage in labor intensive manufacturing production. The model is also built on the fact that 
the processing trade is pervasive in China. The import of intermediate goods also releases labor to more productive manufacturing good sector. I calibrate the model to match relative prices of agricultural good and intermediate good and show that the process of structural transformation in an open economy can generate growth rate of GDP comparable to those observed in China in the period 1991-2004.

Chapter 3 studies how international trade impacts economic growth in general. In this essay, I build a theoretical model to study the effect of trade liberalization on the innovation in an economy. Build on Grossman and Helpman (1991), I combine a creative destruction model with an international trade model with heterogenous firm à la Melitz (2003). I study the balanced growth path of this simple model. Then I examine the impact of trade on economic growth. Trade liberalization in terms of reduction of trade barrier can help reallocate labor to innovation sector and therefore will promote the economic growth of the economy.

Chapter 4 reviews the literature on structural change and its implications for economic development. Developing countries started to develop from reallocating labor in agriculture to industrial production. This essay reviews the two main mechanism to generate structural change in standard models of economic growth. The structural change can arise from the nonhomothetic preference (or "Engle's Law"). Once the food problem is solved for poor countries, they can reallocate labor to manufacturing production. The other mechanism that can generate the structural change is from the different productivity growth across 
sectors. Then I review the application of the framework of structural change to study a variety of issues in developing countries. I also review the recent development of theoretical models of structural change both in closed economy setup and in an open economy setup. 


\section{Chapter 2}

\section{Reallocation, Globalization, and Economic Growth in China}

\section{$2.1 \quad$ Introduction}

China becomes the second largest economy in terms of GDP in the world as this paper is being written. This paper attempts to study the Chinese economy in a global perspective. We emphasize the role of structural transformation and international trade in the reallocation of labor from less productive agricultural sector to more productive final manufacturing sector. The reallocation of labor provides China a comparative advantage in labor intensive manufacturing production.

China started economic reform in 1978. Since then, the growth experience of Chinese economy has been remarkable. During 1978-2003, the growth of GDP of 
China is about $8.4 \%$ per year. Young (2003) documented that the productivity growth in China was still $7 \%$ after accounting for some measurement error in data. Figure 2.1 shows the annual real GDP per capita for China during $1970-2009$.

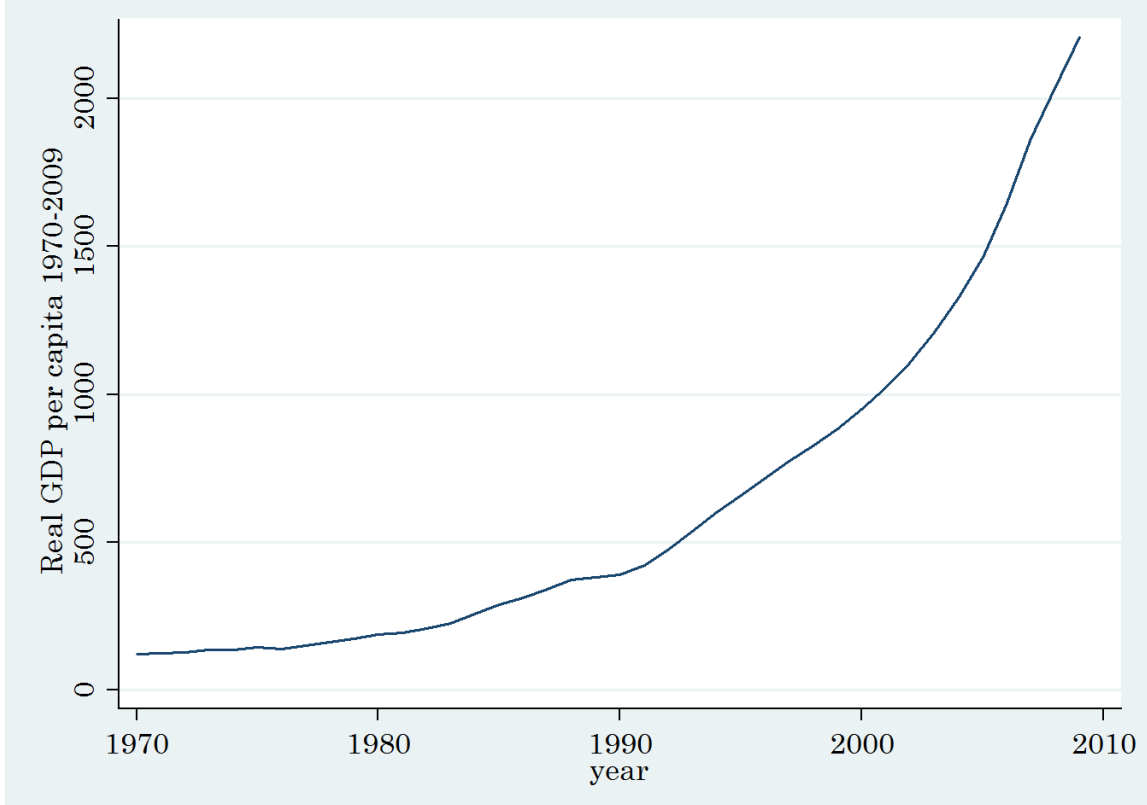

Figure 2.1: REAL GDP PER CAPITA OF CHINA: 1970-2009

Since the inception of economic reform in 1978, the real GDP per capita in China has been steadily growing at a remarkable rate. With the takeoff the economy, the structure of Chinese economy has also been transformed. A large number of workers are reallocated from agricultural sector to manufacturing sector. The reallocation of labor across sectors over time is typically referred as the process of structural transformation in the economic development literature. 
The structural transformation in China provides a comparative advantage in low cost manufacturing for China. With a comparative advantage in the labor intensive industry, China becomes a final processing and assembly platform for a large quantity of imports from other Asian countries to developed countries through China. This paper studies the role of structural transformation and globalization in the process of economic development in China.

The reallocation of labor from less productive agricultural sector to more productive manufacturing sector provides the necessary workers for producing manufacturing goods. A large number of workers from rural area keep the wage low enough to make Chinese exports competitive in the world market. Young (2003) indicates that labor reallocation from agricultural sector is important for China's fast growth during the period between 1978-1998. To better access to the world market, China opened its economy since the beginning of the economic reform. The world market provides both the market for selling final manufacturing goods and the market for importing the intermediate goods. Jones (2011) shows that developing countries are less productive to produce intermediate goods. The import of intermediate good to assemble final manufacturing goods is important for economic development in China. Since China is less productive in producing sophisticated intermediate goods, the import of intermediate goods releases labor to more productive assembling final manufacturing goods. Both structural transformation and the international trade contribute to the reallocation of labor from less productive sectors to more productive sectors. Hence they improve the economic performance of China. This 
paper studies the role of structure transformation and international trade in the reallocation of labor and in turn the economic growth in China. In this paper, I show that both structural transformation and international trade can account for the labor reallocation from agricultural sector to final manufacturing sector in the data. In addition to the existing literature ${ }^{1}$ I find that international trade also plays a very important role in the reallocation of labor from agricultural sector to final manufacturing good sector. Without international trade, labor reallocation process becomes much slower and the decline of labor allocation in agricultural sector is only about $10 \%$. The international trade in the model can account for more than $50 \%$ of decline of labor share in agricultural sector.

In order to formalize the idea, I develop a three-sector neoclassical growth model with structural transformation in an open economy setup. There are three sectors: agricultural sector, intermediate manufacturing good sector, and final manufacturing good sector. In a recent paper Brant, Hsieh, and Zhu (2008), they identify that the central driving force behind structural transformation in China is the improvement in nonagricultural TFP relative to agricultural TFP. In the model, I consider two methods to generate the structural transformation. Following the standard literature on structural transformation, I use a non-homothetic preference with a subsistence consumption level for agricultural good as in Restuccia, Yang, and Zhu (2008). In the model, TFP also grows faster in manufacturing sector relative to agricultural sector. Fast growing manufacturing sector also drives people out of the agricultural sector. Another

\footnotetext{
${ }^{1}$ Most existing literature only emphasizes the process of structural transformation in the labor reallocation process and do not consider the role of international trade.
} 
driving force behind labor reallocation in China is the import of intermediate goods. With large exports, China employs a variety of inputs from foreign countries. Koopman, Wang, and Wei (2008) develops a general formula to estimate that the share of foreign content of China's exports is at about 50\%. For some sectors that are relatively sophisticated such as electronic devices, the share is particularly high and about $70 \%$. In the model, I introduce intermediate good in the production function á la Jones (2011). The share of intermediate good will amplify the effect of productivity growth of manufacturing sector on the labor allocation in equilibrium.

The model in this paper is build in an open economy setup. Even though China exports a lot of manufacturing goods, China does not have a big bargaining power to set the price in the world market. Hence all prices of traded goods in the model are given at the level of international prices. In equilibrium, the international prices levels also affect the labor allocation. Under the international trade, domestic market can also import agricultural good if the domestic price is above the international price. China has to support a large population. To satisfy the subsistence consumption of agricultural good, China has to devote a large fraction of labor into the production of food before China opened its economy to the world market. By importing agricultural good, it can also release the labor to other sectors. Allowing import of agricultural good accelerates the process of structural transformation in China.

The model is calibrated to the data of China to account for the growth experience in China. I find that the model can replicate the labor reallocation 
process in data of China during the period 1991-2004. With international trade, the model predicts a much faster annual growth rate of real GDP than the data shows. In a closed economy, the model fails to account for the growth experience during the period. The model only predicts a $2.4 \%$ annual growth rate of real GDP. This highlights the importance of international trade for the process of economic growth in China. Finally, I relax the subsistence consumption requirement and find that the model can still account for the growth experience though the model predicts a larger decline of labor share in agricultural sector. The model with homothetic preferences predicts an annual growth rate $11 \%$ of real GDP.

\subsubsection{Related Literature}

First, this paper is related with the literature on structural transformation. The theoretical models on structural transformation lie in two lines of research. The first line is based on Kongsamut, Rebelo, and Xie (2001) and emphasizes a role in non-homothetic preferences consistent with Engel's law. The second set of models are based on Baumol (1967) which emphasizes structural change is a result of differential productivity across different sectors. A more recent paper along this line is Ngai and Pissarides (2007). The structural transformation in their model is a result of sector-biased productivity growth and the elasticity of substitution between sectors is less than one. All of these models deal with structural transformation in a closed economy.

Second, this paper extends the models of structural transformation to an 
open economy setup among other papers. Matsuyama (1992) and Matsuyama (2009) first start the discussion of structural transformation in an open economy context. Matsuyama (1992) is close to this paper in the spirit. We both emphasize the role of agricultural sector for structural transformation and study the implication for economic growth. A recent paper Yi and Zhang (2011) introduces Ricardian type international trade model as Eaton and Kortum (2002) into Ngai and Pissarides (2007) to study the structural transformation in an open economy. Another paper Teignier-Baqu (2009) extends a neoclassical growth model into an open economy setup and employs a non-homothetic preference to study the role of international trade in structural transformation. He also calibrates the model to the data of U.K., U.S., and South Korea to explore the quantitative implications of international trade on structural transformation. He finds that the import of agricultural good can accelerate the process of structural transformation.

Thirdly, this paper is related to the research on the transition of Chinese economy. This paper follows Brant and Zhu (2010) and Dekle and Vandenbroucke (2006) to account for growth and structural transformation for Chinese economy. However, these two papers only do the quantitative analysis in a closed economy setup. The contribution of this paper is to extend the analysis to an open economy setup by emphasizing the import of intermediate goods as well. My paper also relates to the literature that studies the role of agricultural sector for economic development. Restuccia, Yang, and Zhu (2008) ${ }^{2}$

\footnotetext{
${ }^{2}$ Other papers discuss the role of agricultural sector including Gollin, Parente, and Rogerson (2007) and Hayashi and Prescott (2008). Gollin, Parente, and Rogerson (2007) studies
} 
emphasizes the food requirement for a country's economic development. With a low productivity level in agricultural sector and subsistence food requirement, developing countries need to put a large number of people working in the agricultural sector to satisfy the food requirement. In an open economy setup, the import of agricultural goods can relax the food requirement problem for China and accelerates the process of structural transformation.

Finally, this paper is related to the literature on resource reallocation on aggregate TFP for Chind ${ }^{3}$, A recent paper on this issue is Hsieh and Klenow (2009). They use establishments level data and find that TFP can gain 30\%$50 \%$ in China after reallocation of capital and labor to equalize the marginal products to the extent observed in the U.S. Another important paper on reallocation within manufacturing sector of Chinese economy is Song, Storesletten, and Zilibotti (2011). They identify that reallocation of labor and capital across manufacturing firms has been a key source of productivity growth. Bajona and Chu (2010) find that the reallocation of resource from state owned sector to non-state owned sector due to the cut of government subsidy required by WTO can provide welfare gains. Along this line of research, I study the reallocation across different sectors and find that reallocation of labor across sectors in China can also improve the growth.

The rest of this chapter is organized as follows. Section 2 documents some

the different economic performance in agricultural sector for countries can account for the different income levels. Hayashi and Prescott (2008) makes the point that the impediment of reallocation from agricultural sector to more productive sector will slow down the economic growth. They show the case for Japanese economy in the prewar period.

${ }^{3}$ Kehoe and Ruhl (2009) studies the resource reallocation between nontraded sector and traded sector of Mexico to account for the output drop after crisis. 
empirical facts about the transformation of Chinese economy. Section 3 describes the economic environment. Section 4 discusses the calibration of the model to the data of Chinese economy. Section 5 reports and discusses the results. Section 6 concludes.

\subsection{Empirical Evidence: The China Miracle}

In this section, we document some of the main empirical facts of China's economic transformation. Figure 2.1 has shown the remarkable growth experience of China since the inception of economic reform. In this section, we mainly document the empirical facts on structural transformation in China.

Since the beginning of economic reform in 1978, the rural population has been declined significantly. Figure 2.2 shows the data on rural population as a percentage of total population from the World Bank.

The percentage of rural population has declined from more than $80 \%$ to slightly above 50\%. During the same period, the value added of agricultural sector has also been decreased sharply. The value added of agricultural sector decreases from about $40 \%$ to $20 \%$ of the aggregate economy.

The reallocation of the labor resource to manufacturing sector provides the productive capacity for large exports to the world market.

One of the main policy of economic reform in China is to open its economy to the world market. Starting from the reform, the international trade as percentage of GDP increases sharply. In December 2001, China entered the WTO 


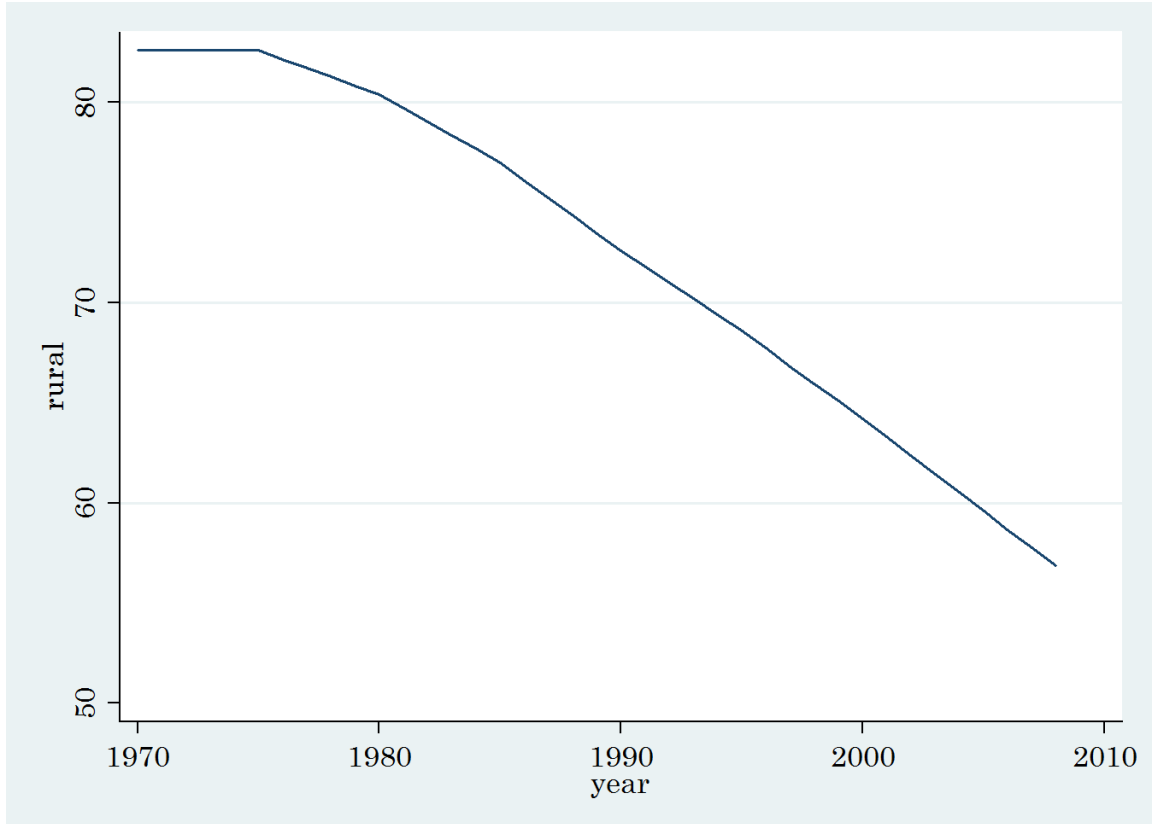

Figure 2.2: Rural Population as a Percentage of Total Population OF CHINA: 1970-2009

and international trade has increased dramatically since the accession to the WTO. Figure 2.4 shows the data of merchandize trade as a percentage of GDP.

On the one hand, China exports a large amount of manufacturing goods to the world market. On the other hand, China imports a lot of raw material and intermediate goods as inputs to produce the manufacturing goods. The processing trade is pervasive in China. 


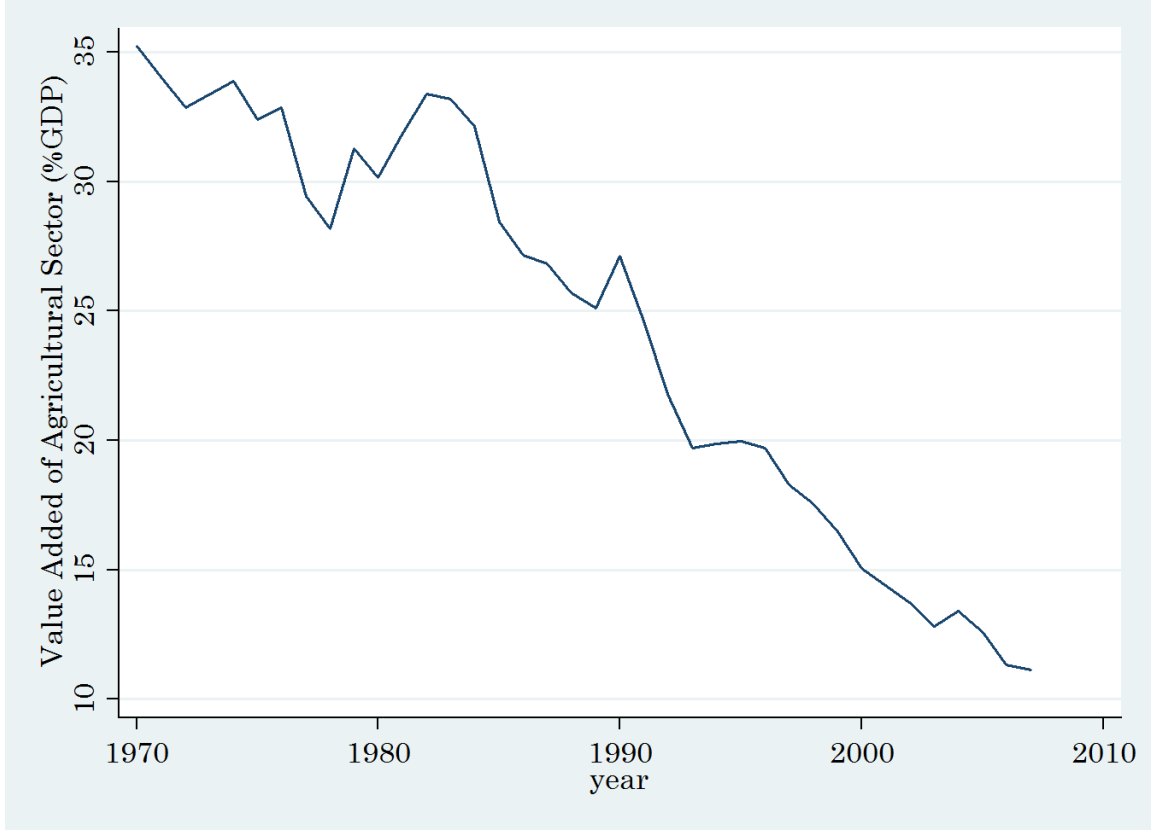

Figure 2.3: VAlue AdDed AS A Percentage of GDP in Agriculture (SOURCE: World BANK World Development Indicators)

\subsection{The Model}

The model is built on models of structural transformation and features both differential productivity growth and non-homothetic preferences. Final manufacturing sector is more productive than agricultural sector and also grows faster than agricultural sector and intermediate good sector. This provides the comparative advantage of manufacturing production and hence the incentive for international trade. In the model, there are three sectors: agricultural sector, intermediate manufacturing good sector and final manufacturing sector. The 


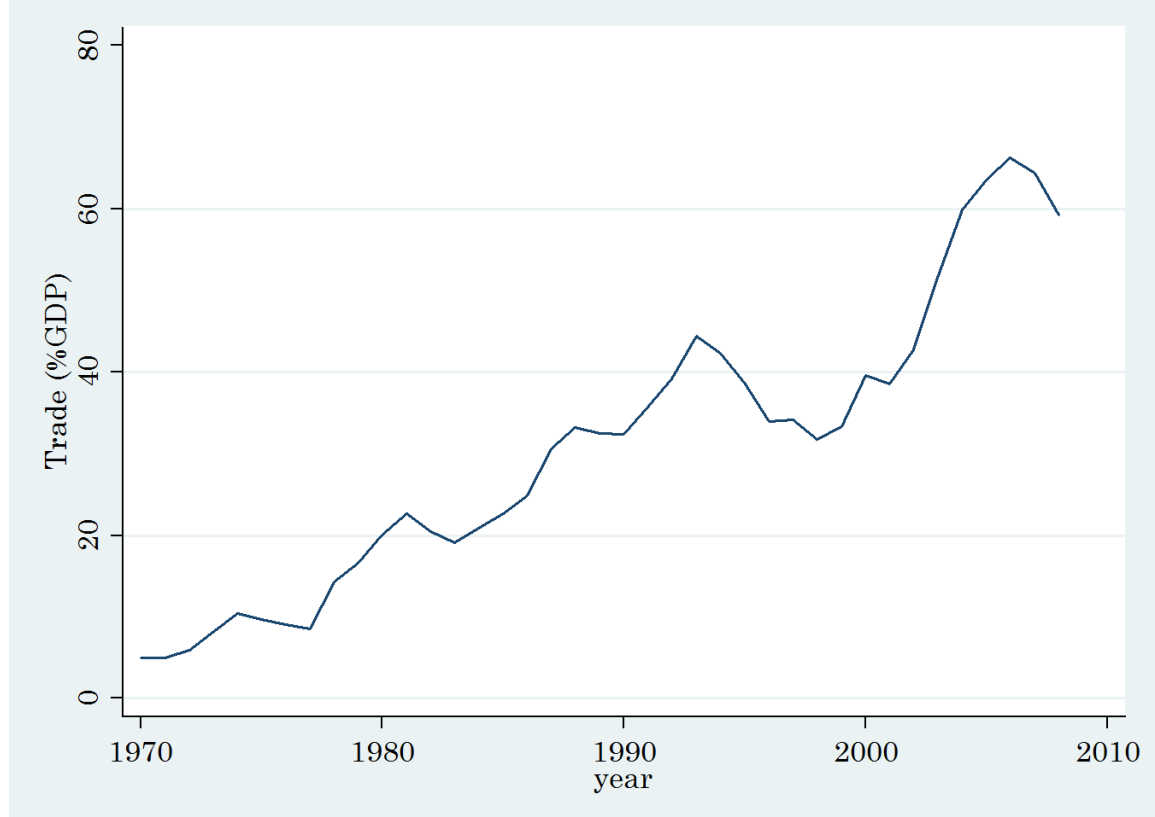

Figure 2.4: International Trade as a Percentage of GDP (Source: WORLD BANK World Development Indicators)

non-homothetic preference imposes a subsistence requirement for household.

\subsubsection{Household}

The representative household consumes both agricultural good and final manufacturing good. Also there is a subsistent level requirement of consumption of agricultural good. The income of household comes from the wage income from selling labor to firms, the rent income from land and rent income from capital. 
The preference of the household is as follows

$$
u\left(c_{a t}, c_{m t}\right)=b \log \left(c_{a t}-\bar{a}\right)+(1-b) \log \left(c_{m t}\right) .
$$

where $c_{a}$ is the consumption of agricultural good, $\bar{a}$ is the subsistence level of agricultural good, and $c_{m}$ is the consumption of manufacturing good. $b$ is a parameter.

The representative household will maximize the life-long discounted utility given by

$$
\sum_{t=0}^{\infty} \beta^{t} u\left(c_{a t}, c_{m t}\right)
$$

where $u\left(c_{a t}, c_{m t}\right)$ is defined above.

The representative household will sell labor to different sectors: agricultural sector, intermediate good sector, and final manufacturing good sector. The total income will be used for consumption and investment. The budget constraint for the representative household is given by

$$
\begin{aligned}
p_{m t+1} I_{t}= & w_{t} L+p_{m t} r_{t} k_{t}+\pi_{t} H-p_{m t} c_{m t}-p_{a t} c_{a t} \\
k_{t+1}= & (1-\delta) k_{t}+I_{t} \\
& k_{0} \text { is given. }
\end{aligned}
$$

where $I_{t}$ is the investment, $L$ is the total labor endowment, $k_{t}$ is capital, $H$ is land in fixed supply and $w_{t}$ is the wage rate for working in different sectors, $r_{t}$ is the rental rate on capital, $\pi_{t}$ is the rental rate on land, $p_{m t}, p_{a t}$ are prices on 
final manufacturing good and agricultural good respectively.

The representative household's problem is to maximize the life-long utility (2.2) subjective to budget constraints (2.3) and (2.4).

\subsubsection{Technologies}

There are three sectors in the model. Each sector has its own technology. The technology for agricultural good sector is given by

$$
Y_{a t}=A_{a t} l_{a t}^{\gamma} H^{1-\gamma}
$$

where $Y_{a t}$ is the output of agricultural good sector, $A_{t}$ is the productivity of the sector, $l_{a t}$ is the labor allocation of the sector, $H$ is the land endowment in fixed supply. $\gamma$ is the parameter of labor income share of agricultural sector and is between zero and one. Agricultural good is produced by labor and land.

The technology for final manufacturing good sector is given by

$$
Y_{m t}=A_{m t}\left(k_{m t}^{\alpha} l_{m t}^{1-\alpha}\right)^{1-\sigma} X_{t}^{\sigma}
$$

where $Y_{m t}$ is the output of final manufacturing good sector, $A_{m t}$ is the productivity of the sector, $k_{m t}$ is the capital used in the sector, $l_{m t}$ is the labor allocation in this sector, $X_{t}$ is the intermediate good used in the production of final manufacturing good. $\alpha$ and $\sigma$ are parameters of income share of capital and intermediate goods. Both parameters $\alpha$ and $\sigma$ is assumed between 0 and 1 . 
The technology for intermediate manufacturing good sector is given by

$$
Y_{i t}=A_{i t} l_{i t}
$$

where $Y_{i t}$ is the output of intermediate good sector, $A_{i t}$ is the productivity, and $l_{i t}$ is the labor allocation to intermediate good sector. We assume that intermediate good is only produced by labor. Later, we will focus on the case that intermediate good will be imported from foreign countries since the domestic country is not productive at producing the intermediate good. This is also consistent with the fact that China has imported a large share of intermediate good as I mentioned in the Introduction.

The firms' problems are to maximize their profits given the prices.

Final Manufacturing good producer's problem: Taking the prices of $p_{m t}, p_{i t}$ and factors returns on labor and capital as given, the representative firm in the final manufacturing good sector is to maximize

$$
\max p_{m t} A_{m t}\left(k_{m t}^{\alpha} l_{m t}^{1-\alpha}\right)^{1-\sigma} X_{t}^{\sigma}-w_{t} l_{m t}-r_{t} k_{m t}-p_{i t} X_{i t}
$$

Similarly, taking the prices of $p_{a t}$ and factors return on labor $w_{t}$ and land $\pi_{t}$ as given, the representative firm in agricultural sector solves the following problem

$$
\max p_{a t} A_{a t} l_{a t}^{\gamma} H^{1-\gamma}-w_{t} l_{a t}-\pi_{t} H
$$

And taking the price $p_{i t}$ and wage of labor $w_{t}$ as given, the representative firm 
in intermediate good sector solves the following problem

$$
\max p_{i t} A_{i t} l_{i t}-w_{i t} l_{i t}
$$

\subsubsection{Equilibrium}

First, I consider an open economy setup. Here I study a special case of equilibrium. In this equilibrium, the domestic country has a comparative advantage in producing final manufacturing good and the rest of world has a comparative advantage in producing intermediate good. Hence the pattern of trade is that China imports intermediate manufacturing good and export final manufacturing good. The trade pattern here I consider is consistent with the actual trade pattern for China. Even though China imports and exports a lot of manufacturing goods in the world market, China still does not have much bargaining power in the world market. Hence I assume that China takes all international prices of traded goods as given by the world market. We study an equilibrium of this small open economy.

The definition of an equilibrium of the economy is given as follows.

Definition 1 Given initial resources endowments $\left\{k_{0}, L, H\right\}$ and international prices $p_{a t}^{*}, p_{i t}^{*}, p_{m t}^{*}$ in the world market, also given the sequences of factor rental prices $\left\{w_{t}, r_{t}, \pi_{t}\right\}$, a competitive equilibrium is a sequence of household consumption plans $\left\{c_{a t}, c_{m t}\right\}$ and production plans of firms $\left\{y_{a t}, y_{m t}, y_{i t}, k_{t}, l_{a t}, l_{i t}, l_{m t}\right\}$ such that

- The representative household chooses the consumption plans $\left\{c_{a t}, c_{m t}\right\}$ 
and $k_{t}$ to solve utility maximization problems.

- Firms choose production plans to solve profit maximization problems and earns zero profit in equilibrium.

- All markets clear.

- commodity market clearing conditions:

$$
\begin{aligned}
y_{m t} & =c_{m t}+I_{t}+x_{m t}, \\
y_{a t} & =c_{a t}-m_{a t}, \\
X_{t} & =m_{i t} .
\end{aligned}
$$

where $x_{m t}$ is the export of final manufacturing goods, $m_{a t}$ is the import of agricultural good, and $m_{i t}$ is the import of intermediate manufacturing good.

- $\quad$ - Labor market clearing condition

$$
l_{a t}+l_{m t}=L
$$

where $L$ is the total labor endowment.

- Trade is in zero balance 4

$$
p_{m t}^{*} x_{m t}=p_{i t}^{*} m_{i t}+p_{a t}^{*} m_{a t} .
$$

\footnotetext{
${ }^{4}$ Since the trade balance of China does not change very much over time, to add a surplus term in the model will not change the result.
} 
- And the no-arbitrage condition between the capital and land assets holds.

\subsubsection{Characterization}

The analysis of the model starts from the household problem. All the derivations are gathered in the appendix. The solutions to household problem give us the consumption plan.

$$
\begin{aligned}
c_{a t} & =\frac{b\left(w_{t} L+\pi_{t} H+r_{t} k_{t}\right)+(1-b) p_{a t} \bar{a}}{p_{a t}} \\
c_{m t} & =\frac{(1-b)\left(w_{t} L+\pi_{t} H+r_{t} k_{t}-p_{a t} \bar{a}\right)}{p_{m t}}
\end{aligned}
$$

From above two equations, we can know that the requirement of subsistent level of consumption $\bar{a}$ is important for allocation of consumption. If the value of $\bar{a}$ is very high, then the consumption of agricultural good is also high. It will need more resource to allocate to agricultural sector and impede the development.

The solutions to firms problems give us the labor allocation in different sectors given prices. The FOCs for firm's problem in agricultural sector are given by

$$
\begin{aligned}
w_{t} & =\gamma p_{a t} A_{a t} l_{a t}^{\gamma-1} H^{1-\gamma} \\
\pi_{t} & =(1-\gamma) p_{a t} A_{a t} l_{a t}^{\gamma} H^{-\gamma}
\end{aligned}
$$


These two equations also give us the wage and rental rate on land in the agricultural sector. Combining these two equations, we can obtain a equation for labor allocation in agricultural sector.

$$
l_{a t}=\left(\frac{1}{1-\gamma}\right)^{\frac{1}{\gamma}}\left(\frac{\pi_{t}}{p_{a t} A_{a t}}\right)^{\frac{1}{\gamma}} H^{\gamma}
$$

From the above equation, we can know that labor allocation in agricultural sector depends on the rent on land, price of agricultural sector and productivity of agricultural good. In addition, from eqs. 2.18 and 2.19 we can obtain

$$
\frac{\gamma}{1-\gamma} \frac{H}{l_{a t}}=\frac{w_{t}}{\pi_{t}}
$$

We will use this equation to calibrate the share of labor in agricultural sector.

Solving firm's problem in final manufacturing good sector gives us the following FOCs

$$
\begin{aligned}
(1-\sigma)(1-\alpha) p_{m t} A_{m t}\left(k_{t}^{\alpha} l_{m t}^{1-\alpha}\right)^{-\sigma} X_{t}^{\sigma} k_{t}^{\alpha} l_{m t}^{-\alpha} & =w_{t} \\
(1-\sigma) \alpha p_{m t} A_{m t}\left(k_{t}^{\alpha} l_{m t}^{1-\alpha}\right)^{-\sigma} X_{t}^{\sigma} k_{t}^{\alpha-1} l_{m t}^{1-\alpha} & =r_{t} \\
\sigma p_{m t} A_{m t}\left(k_{t}^{\alpha} l_{m t}^{1-\alpha}\right)^{1-\sigma} X_{t}^{\sigma-1} & =p_{i t}
\end{aligned}
$$

From eqs. 2.22 to (2.24), we can obtain several ratios of resource allocation which will be used to calibrate the parameters in the next section. From eq. (2.22) and eq. (2.23), we can obtain the ratio of labor allocation and capital 
used in the final manufacturing sector that depends on the factor returns.

$$
\frac{1-\alpha}{\alpha} \frac{k_{t}}{l_{m t}}=\frac{w_{t}}{r_{t}}
$$

The demand for intermediate good is given by

$$
\frac{X_{t}}{k_{t}^{\alpha} l_{m t}^{1-\alpha}}=\left(\frac{p_{i t}}{p_{m t} A_{m t} \sigma}\right)^{\frac{1}{\sigma-1}}
$$

In equilibrium, the return on land and capital must be equal in the absence of arbitrage opportunity. This implies that

$$
\frac{1-\alpha}{\alpha} \frac{k_{t}}{l_{m t}}=\frac{\gamma}{1-\gamma} \frac{H}{l_{a t}}
$$

From the FOCs for three different firms and also the market clearing conditions for labor market, we can obtain the expression for labor allocation in agricultural sector. The result is summarized in the following proposition.

Proposition 2 The labor allocation in the agricultural sector is given by

$$
\left(l_{a t}\right)^{1-\gamma-\alpha}=\Omega\left(\frac{A_{a t}}{A_{m t}^{1 /(1-\sigma)}}\right)\left(\frac{p_{a t}}{p_{m t}}\right)\left(\frac{p_{i t}}{p_{m t}}\right)^{\frac{\sigma}{1-\sigma}}
$$

where $\Omega$ is parameter which depends on $\alpha, \gamma, \sigma$.

Proof. See the Appendix.

From eq. 2.28), we can see that the labor allocation of agricultural sector 
depends on the relative productivity of agricultural sector to final manufacturing good sector. If the growth of productivity in final manufacturing good sector outweighs the growth of productivity in agricultural sector, then the labor allocation is reallocated to the more productive final manufacturing good sector. This is the reallocation effect driven by the differential productivity 5 . Notice also the labor allocation in agricultural sector depends on the relative price of agricultural good to final manufacturing good. A reduction of relative agricultural good will reduce the allocation of labor to agricultural sector. If the country opens to international trade and import the agricultural good, this will reduce the relative price of agricultural good. Labor will also be reallocated to the other sector. This is the reallocation effect due to international trade. Similarly, the reallocation effect can also happen if I allow the import of intermediate manufacturing good. We can also notice that the role of intermediate good share $\sigma$. Here $\sigma$ is similar to a "multiplier" on the productivity of final manufacturing good sector. This is different from a standard model without intermediate good 6 , Given the specific value of $\sigma$ as shown in the data for China7, the term $\frac{\sigma}{1-\sigma}$ can also serve as a "multiplier" to amplify the effect of reduction in the price of intermediate good. Hence the labor reallocation effect is amplified by including intermediate good since all the production activities are correlated through intermediate goods.

\footnotetext{
${ }^{5}$ This is the machanism that emphasizes in the papers Baumol (1967) and Ngai and Pissarides (2007)

${ }^{6}$ However, this is similar to Jones (2011). In his paper, the intermediate good share also has a role of "multiplier".

${ }^{7}$ In the data, $\sigma$ is 0.64 for China as suggested by Jones (2011).
} 
In the next section, we use data of China to calibrate the model based on the eq. 2.28).

\subsection{Calibration}

In this section, I calibrate the model in the previous section to match the data of China. I use the FOCs derived in the previous section to calibrate the parameters of capital share $\alpha$ and labor share $\gamma$ to match the data in input-output table of China. The calibrated values of parameters are reported in Table 2.1 as follows.

Table 2.1: Calibration of Parameters

\begin{tabular}{lcc}
\hline \hline \multicolumn{1}{c}{ Parameter } & Value & Target \\
\hline \hline Capital share in manufacturing sector $\alpha$ & 0.41 & capital share in I/O \\
Labor share in agricultural sector $\gamma$ & 0.52 & labor share in I/O \\
Intermediate good share $\sigma$ & 0.60 & I/O table \\
\hline \hline
\end{tabular}

To calibrate the model to the data, we need to specify the productivity growth process. I assume that final manufacturing sector is more productive than agricultural sector in the initial period. Following the literature on estimation of productivity of China, I assume that productivity grows at $3 \%$ per year for final manufacturing sector and no growth in agricultural sector for normalization. Hence this assumption has already take the productivity growth in agricultural sector into consideration. Since in the model, the labor allocation only depends on the relative productivity of agricultural sector to final manufacturing sector, I can normalize the productivity growth of agricultural sector 
to be zero.

To construct the series of international prices, I use unit value to approximate the international prices. It is usually difficult to obtain price data in international trade. Usually, unit value is used to approximate the price data. I obtain data of quantity and value of international trade data between China and the U.S. from OECD SITC (rev. 2). I obtain the quantity and value data and calculate the unit value. For agricultural price, I use the unit value data of wheat to approximate the price of agricultural good. I choose the data between China and U.S.. For agricultural good, I use the data on quantity and value of export of wheat from U.S. to China. This data is available from OECD. I choose textile commodity as the final manufacturing good since China exports a lot of this kind of commodity to the world market. The intermediate good that I choose is the cotton fabrics to produce the textile product. I use the quantity and value data of import of cotton fabrics from U.S. to China to calculate the international price of intermediate good. Also for final manufacturing good textile product, I use the quantity and value of export from China to U.S. to calculate the unit value as an approximation of the international price of final manufacturing price. The problem with this method is that it will bring a large fluctuation of the results when we simulate the model.

After the calibration of the model, I simulate the model for the period from 1991 to 2004 due to restriction of data availability of quantity of trade between China and U.S.. The results are discussed in the next section. 


\subsection{Results}

In this section, I report and discuss the results for different cases. Specifically, I consider three different cases of the model. First, I simulate the model in the open economy setup for the period 1991 - 2004. Then I consider an experiment to switch off all international trade and to compare with the case of an open economy. Finally, I consider the homothetic preferences case in which the preferences are no longer subject to a subsistence consumption requirement. A preview of the results is shown in Table 2.2 as follows.

Table 2.2: RESUlts

\begin{tabular}{lccccc}
\hline \hline & Data & Baseline & Closed & Homothetic & No Import of \\
Economy & Preferences & Intermediate \\
\hline \hline Labor Allocation & $40 \%$ & $42 \%$ & $10 \%$ & $79 \%$ & $70 \%$ \\
Growth of GDP & $8.6 \%$ & $13.5 \%$ & $1.7 \%$ & $11.1 \%$ & $5.7 \%$ \\
\hline \hline
\end{tabular}

In the open economy, I assume that domestic country is a price taker and therefore all international prices are taken as given. In the last section, I have discussed the way I construct the series of international prices for agricultural good, intermediate good, and final manufacturing good.

I simulate the model for the period 1991-2004. The result is given by Figure 2.5 for allocation of labor in the agricultural sector. Basically, the model of open economy version we consider in Section 3 can replicate the data for the period 1991-2004.

We observe that there are some fluctuations in the model since the international prices fluctuate. In the data during 1991-2004, the labor has been 


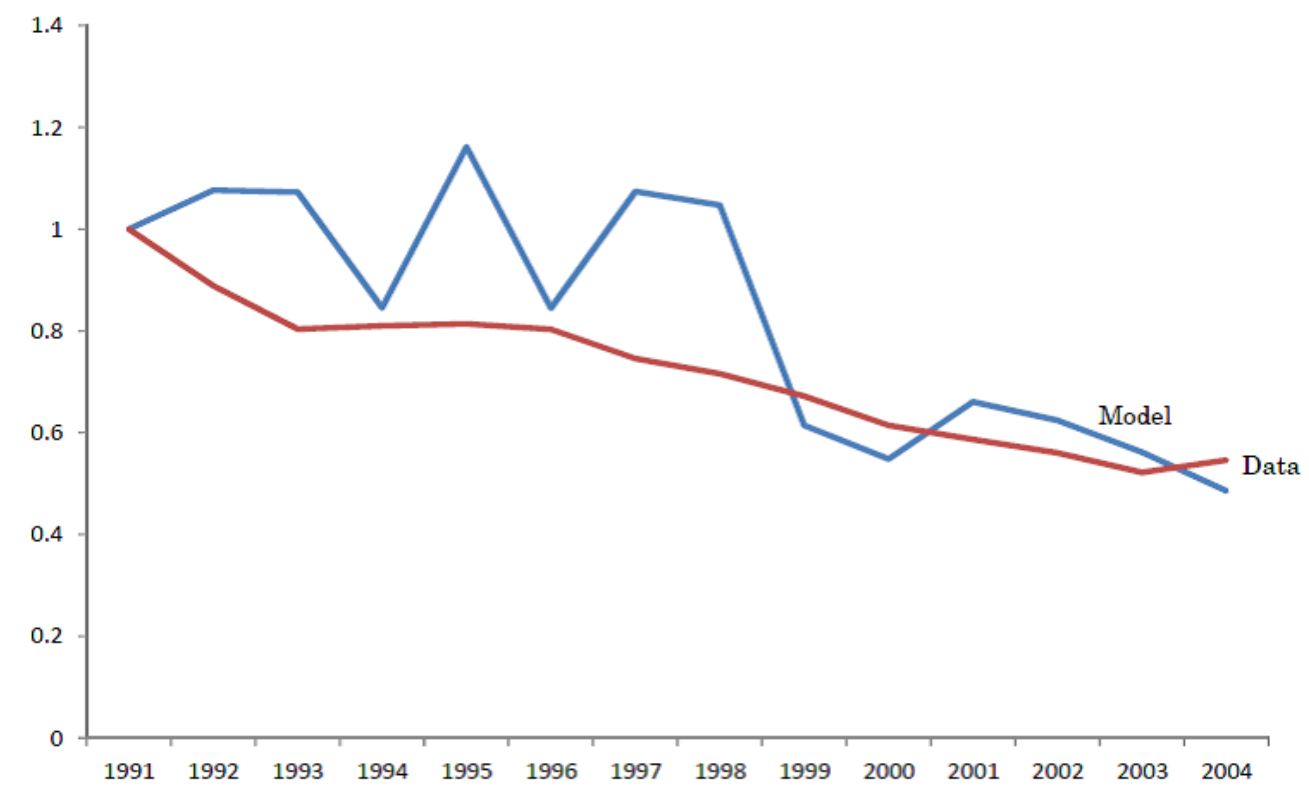

Figure 2.5: Labor Allocation in Agricultural Sector (open econOMY SETUP): 1991-2004

declined by $40 \%$ and the model predicts that labor in the agricultural sector is declined by $42 \%$.

The real GDP in the model is calculated as

$$
G D P=p_{a 0} Y_{a t}+p_{m 0} Y_{m t}-p_{i 0} X_{t}
$$

where $p_{a 0}, p_{m 0}, p_{i 0}$ are prices measured in the base period. The simulation results are given by Figure 2.6. 


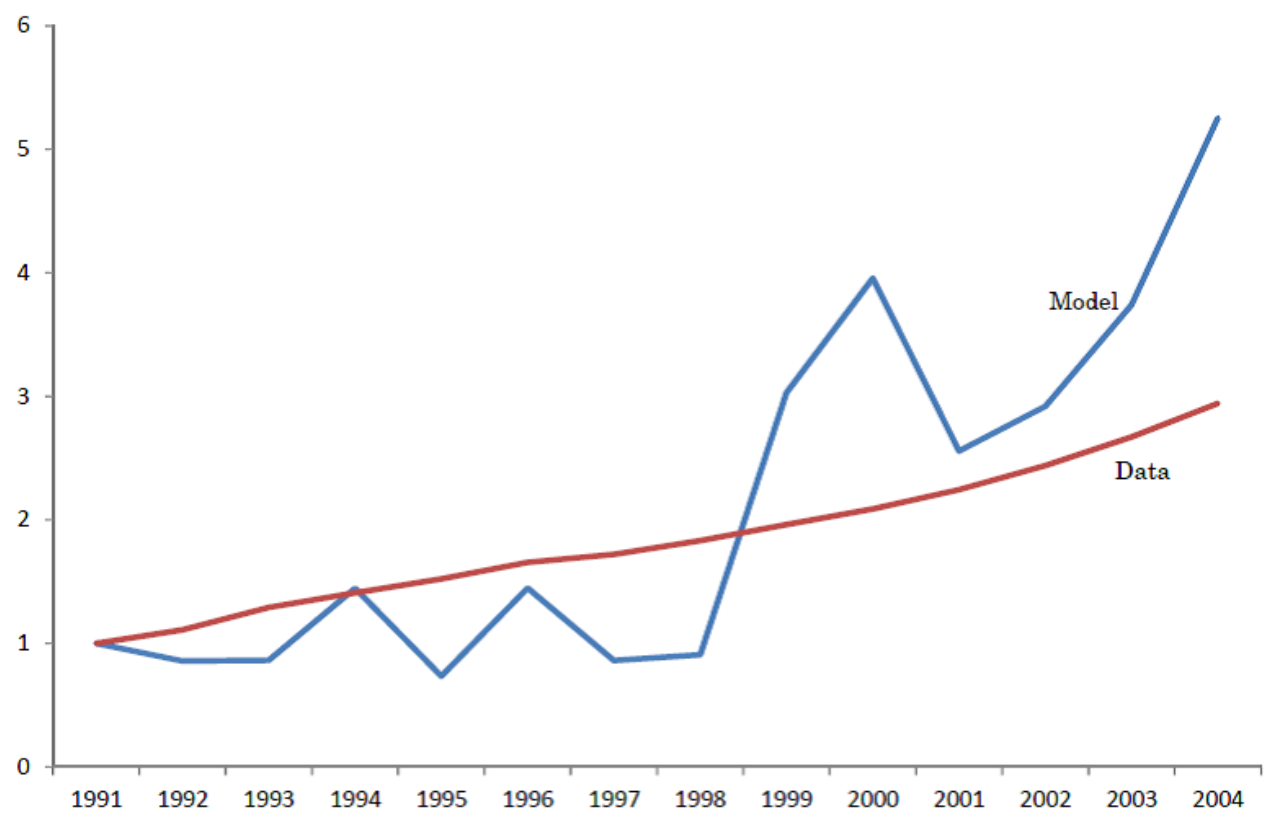

Figure 2.6: REAL GDP (OPEN ECONOMY SETUP): 1991-2004

Basically, the model replicates the data. However, GDP in the model grows much faster than GDP in the data after 2001. In the data, the average growth rate of real GDP during 1991-2004 was about 8.6\%. However, the model predicts an annual growth rate of more than $10 \%$. This could be driven by the fluctuations of international prices in the data. The result in this case depends heavily on the international prices. One possible explanation of the much higher growth of real GDP in the model is China's accession to WTO and the output of final manufacturing good increases due to the large demand from the rest of 
world.

To make comparison and examine the role of reallocation, I then consider a closed economy version of the model. The difference between open economy version and closed economy version are the endogenous prices. In closed economy, prices of all three goods are determined by the market clearing conditions. Since we switch off the international trade, we can expect that the prices of agricultural good and intermediate good must increase. From the Proposition 2 , we know that this will impede the reallocation of labor from agricultural sector to final manufacturing sector. The results are given by Figure 2.7 .

From Figure 2.7, we can see that the reallocation is not clearly shown and is about $10 \%$ which is far lower than the data shows. The slightly decrease of labor allocation in agricultural is driven by the productivity growth. Comparing Figure 2.7 and Figure 2.5, we can see that international trade has played a very important role in the reallocation process. The globalization can account for more than $50 \%$ of the reallocation of labor from agricultural sector to the final manufacturing sector as suggested by the model.

The similar conclusion can be drawn for real GDP as shown in Figure 2.8.

Without the international trade, the growth of real GDP slows down. However, the productivity growth still contributes to the growth of the economy. Also from the comparison between Figure 2.6 and Figure 2.8, we can notice that the important role of reallocation of resource in the process of economic development. The impediment of resources reallocation makes the economy grow slower. 


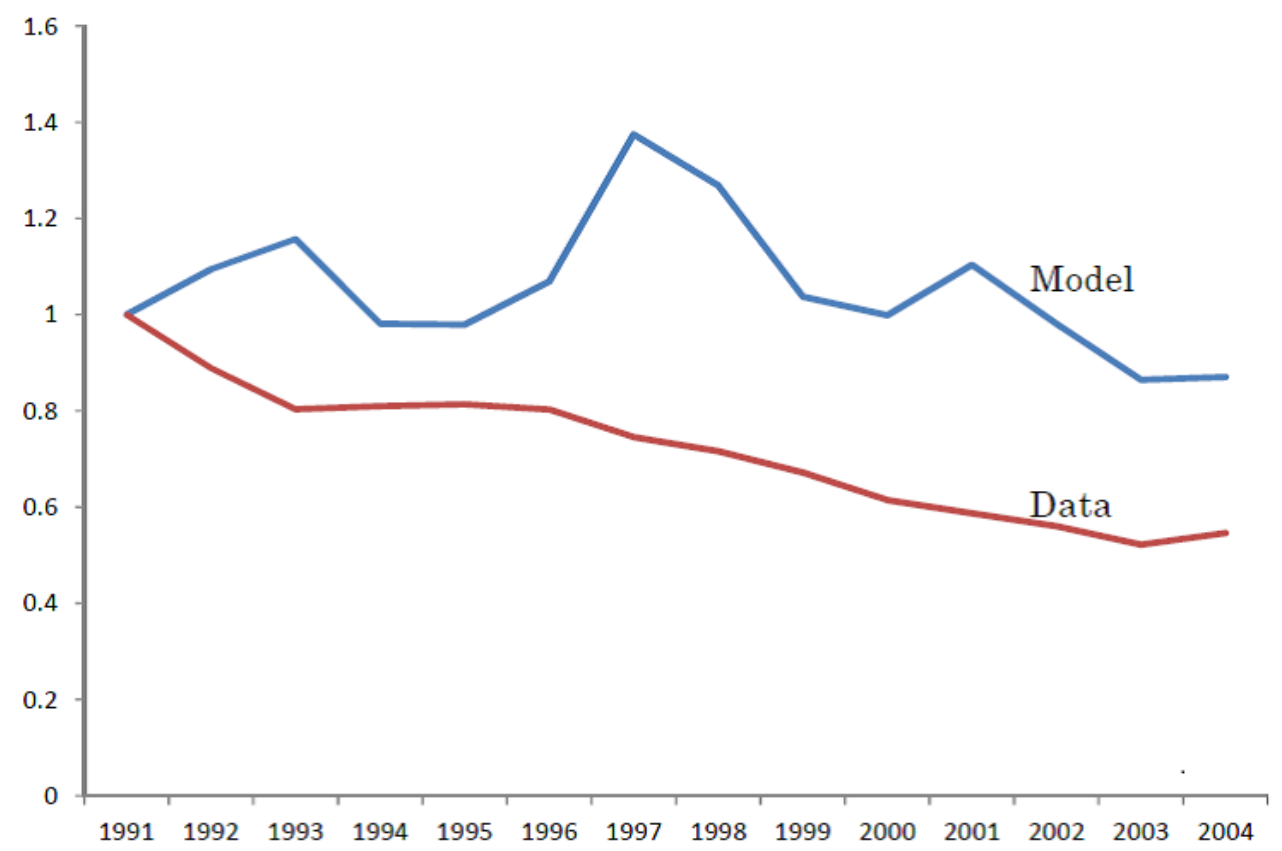

Figure 2.7: Labor Allocation in Agricultural Sector (Closed EConOMY SETUP): 1991-2004

In another numerical example, I relax the subsistence consumption requirement i.e., set $\bar{a}=0$. In this case, I also consider the the implications of the model for labor reallocation and real GDP. The reallocation of labor is shown in Figure 2.9.

The model predicts a larger share of labor has been reallocated away from agricultural sector as opposed to the data. In the case of homothetic preference, the relax of subsistence consumption requirement accelerate the reallocation process of labor to faster growing manufacturing sector. We no longer need to 


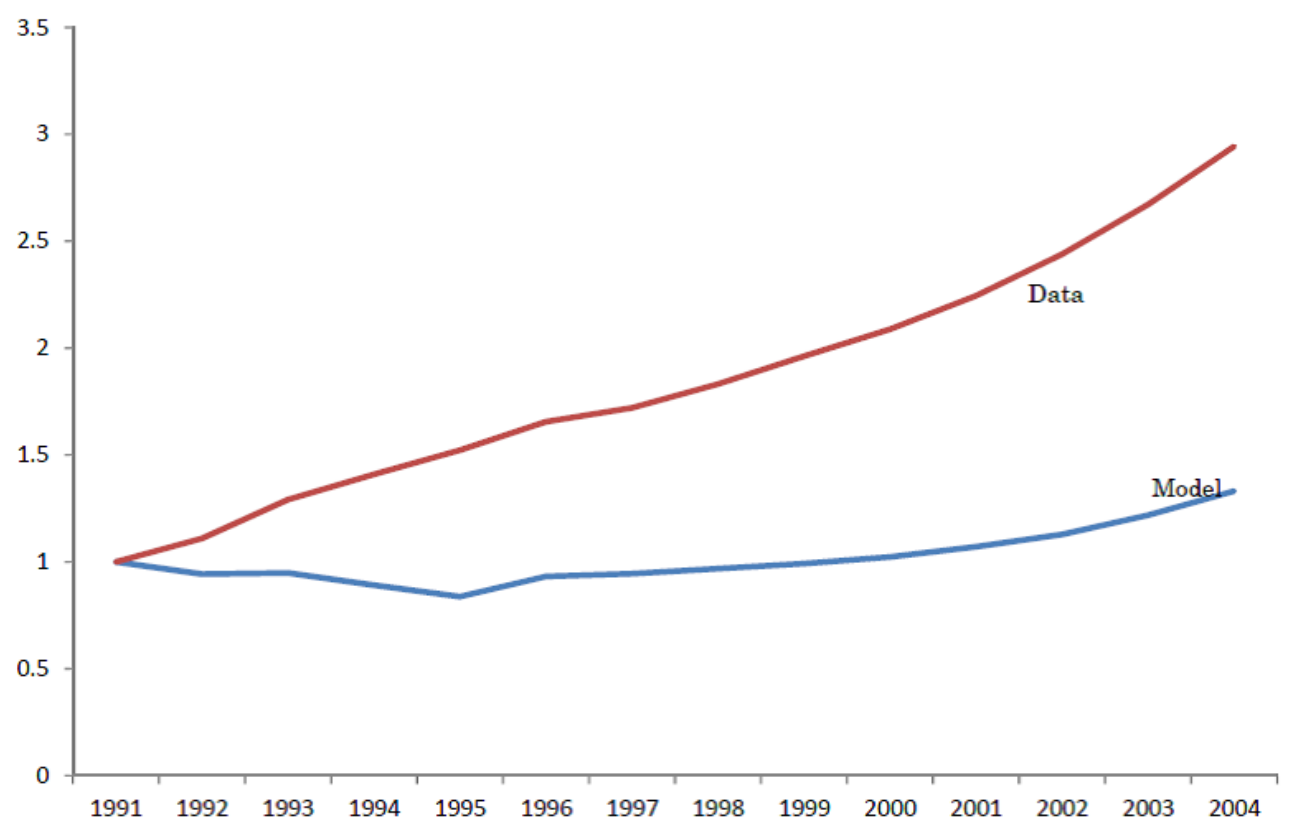

Figure 2.8: REAL GDP (CLOSED ECONOMY): 1991-2004

allocate a fixed amount of labor to produce the subsistence level of agricultural good.

The result of real GDP is shown in Figure 2.10.

The model implies a faster growth rate of real GDP during the period than the case of closed economy. This shows that the importance of a subsistence consumption requirement. The subsistence consumption requirement of agricultural good can be a big obstacle for the development of an economy. This is consistent with the findings of Gollin, Parente, and Rogerson (2007). 


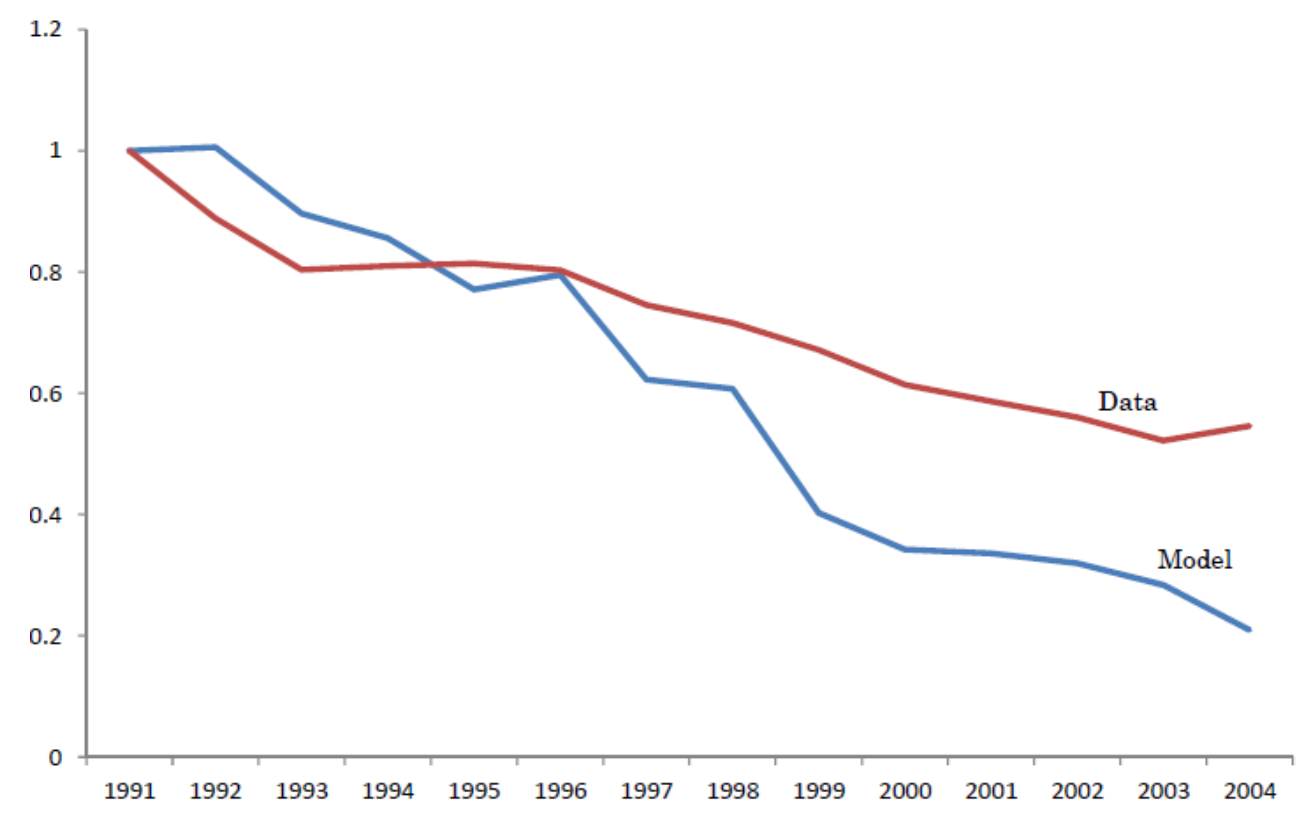

Figure 2.9: Labor Allocation in Agricultural Sector (Homothetic Preferences): 1991-2004

In this experiment, I consider a situation with no import of intermediate good. However, I still allow the international trade of agricultural good. Hence the reallocation process can also be accelerated by importing the agricultural good. The growth of GDP will be impeded by allocating labor to less productive sector. The reallocation process is reported in Figure 2.11.

The model can replicate the reallocation process of labor comparable with the data implies. The GDP grows slower than what the data shows. This experiment highlights the importance of import of intermediate good. Figure 2.12 


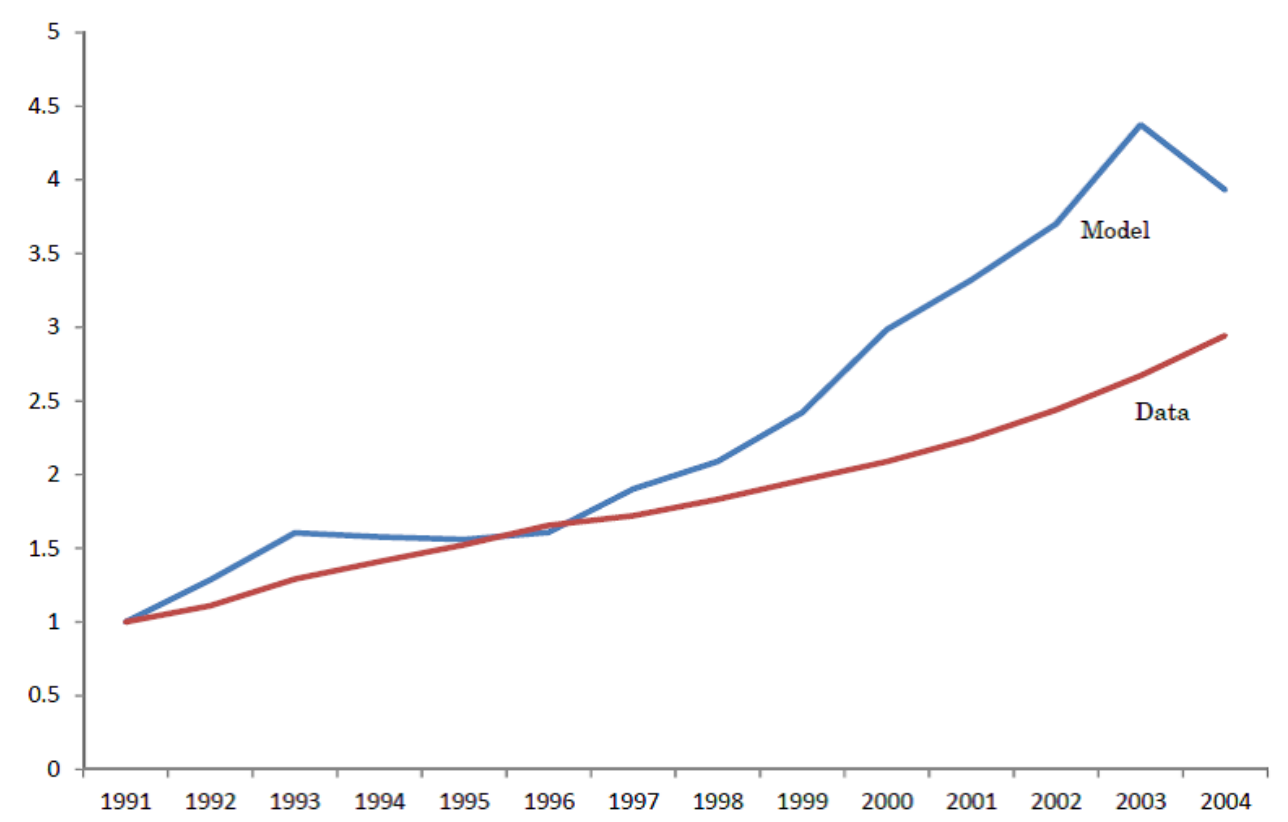

Figure 2.10: Real GDP (Homothetic Preferences): 1991-2004

shows the process for real GDP.

Without the import of intermediate good, GDP grows much slower than open economy case.

\subsection{Concluding Remarks}

In this paper, I construct a three sector growth model in an open economy setup to study the reallocation of resource across different sectors for China. 


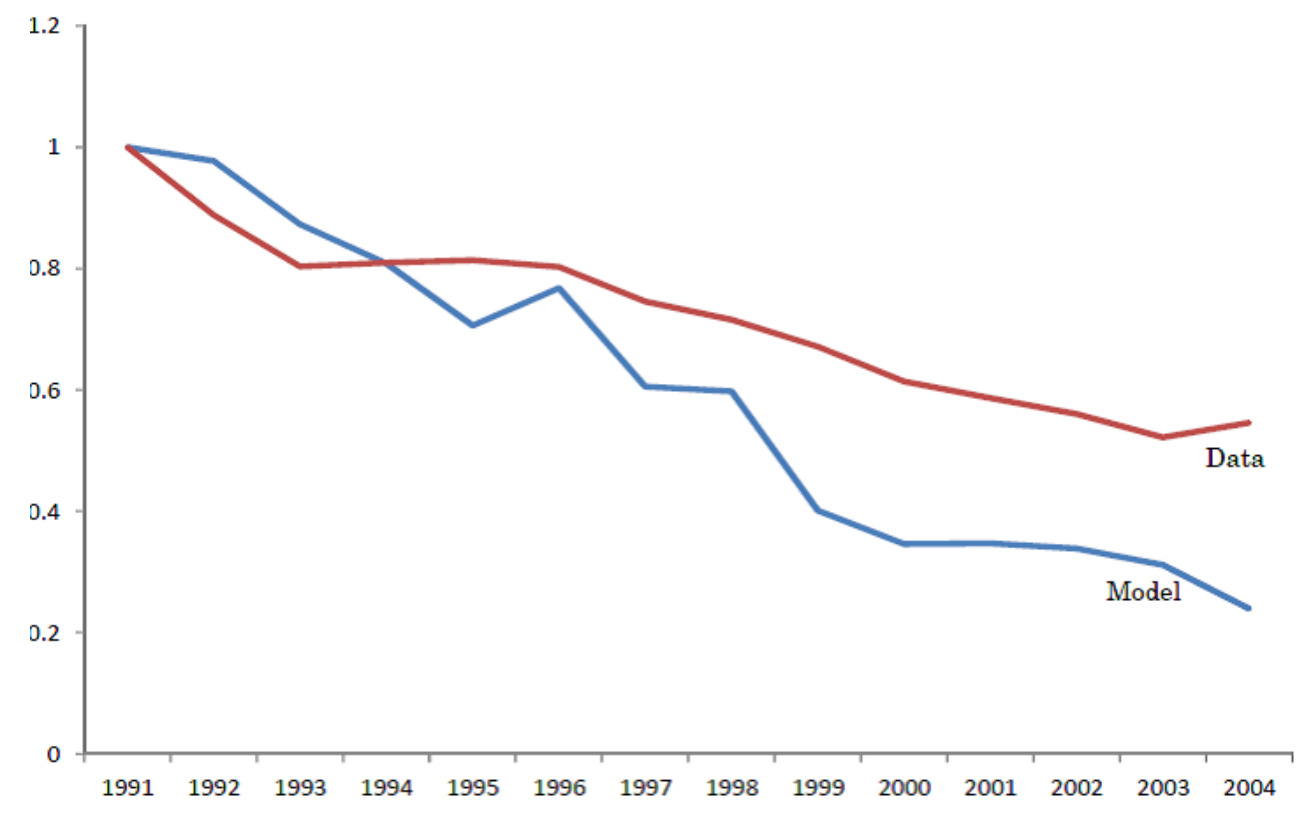

Figure 2.11: Labor Allocation in Agricultural Sector (No Import of Intermediate Good): 1991-2004

Specifically, I study the role of structural transformation and globalization on the reallocation of labor resource from less productive agricultural sector to relatively more productive final manufacturing good sector.

I find that both structural transformation and globalization can contribute to the reallocation of resource from agricultural sector to final manufacturing sector. The globalization plays a more important role for resource reallocation. This is largely ignored in the existing literature which most emphasizes the reallocation effect due to structural transformation. I also find that the reallocation 


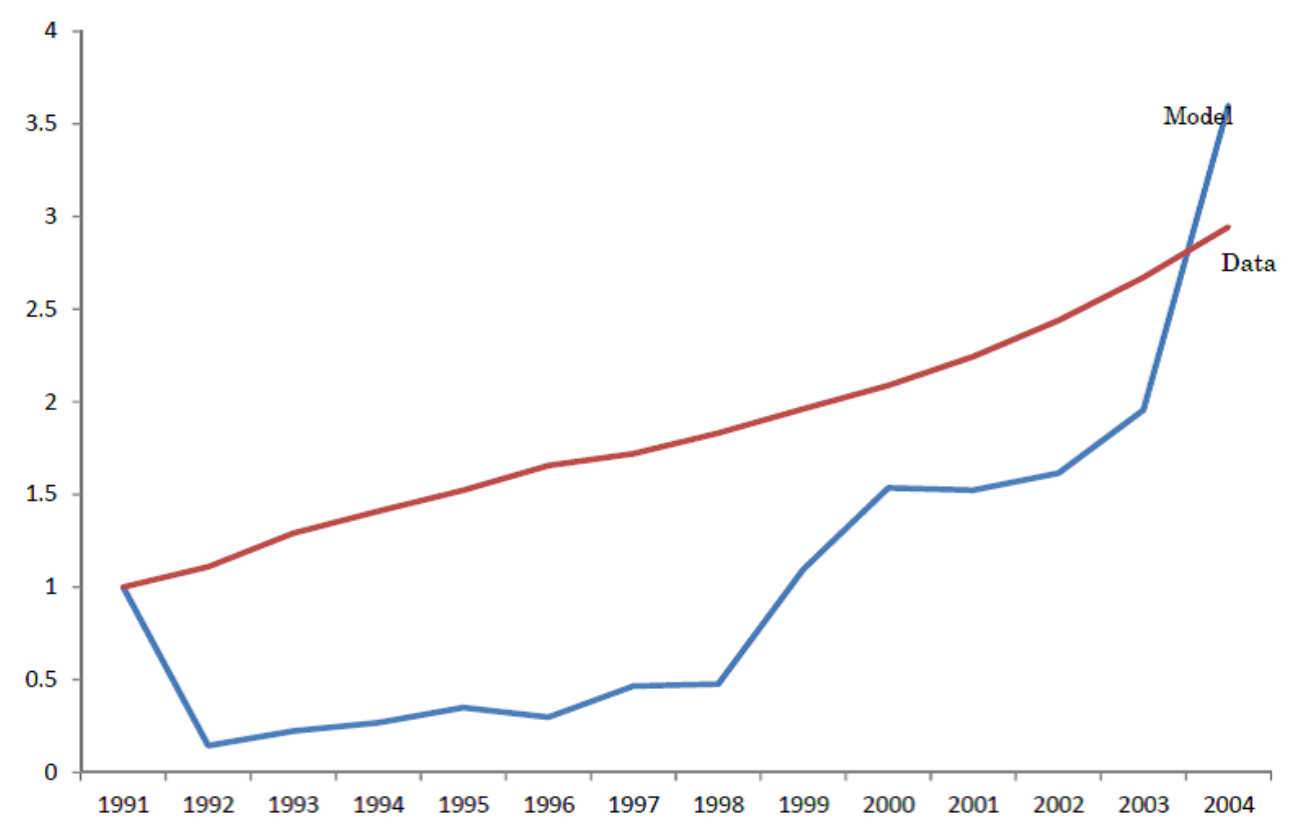

Figure 2.12: Real GDP (No Import of Intermediate Good): 19912004

arising from globalization has a large effect on the economic growth of the Chinese economy during 1991-2004. This is also suggested in Jones (2010) as a hot topic studied in the current literature of economic growth.

In this paper, I only consider the economy of China and studied the importance of resource reallocation and economic growth. However, liberalization of international trade cannot always bring a bright future for a country's economy. There is no simple relation between trade and growth as shown in Kehoe and Ruhl (2010). Similar development strategy has been adopted by South Korea 
during 1960s and it did contribute to the growth miracle of South Korea as shown in Connolly and Yi (2009). However, the similar development strategy does not work in Mexico as documented by Kehoe and Ruhl (2010). Hence there must be some missing factors that can also link international trade and economic growth for a country and they will be left for future exploration. 


\section{Chapter 3}

\section{When Schumpeter meets Melitz: An Endogenous Growth Model with Heterogeneous Firms}

\subsection{Introduction}

Recent empirical evidence shows that the heterogeneity among different firms is crucial for understanding the within industry trade. Since Melitz (2003), trade literature has introduced firm level heterogeneity into international trade models to account for the new empirical facts at the firm level. Firm level empirical evidence shows that there are large and persistent productivity differences across firms. However, these findings have not been reflected in the literature of endogenous economic growth. 
Pioneered by Romer (1986) and Romer (1990), endogenous growth literature focuses on the introduction of new goods. They assume that every firm has the same productivity level and those endogenous growth models are studied in a closed economy. Hence, when we study these models in open economy, all the firms will export. However, this is not consistent with the firm level empirical evidence of trade. Firm level empirical evidence shows that not all the firms will export even in the traded goods sector. To consider the economic growth in an open economy, we need to take firm heterogeneity into consideration by assuming that firms have different productivity levels.

There is a large literature on the impact of international trade on economic growth. A recent paper Lucas (2009) shows that openness can contribute to the economic growth. Lucas (2009) emphasizes the importance of flow of ideas among different countries especially flow to the underdeveloped countries. He argues that it is the flow of idea that is the main force to reduce the income inequality and for the convergence of growth to a common growing level. Lucas (2009) uses a simple mechanical model to describe the flow of ideas. The key parameter of the model is calibrated from the open economies which is based on Sachs and Warner's classification Sachs and Warner (1995). He finds that income levels and growth rates converge in open economies. However, Lucas (2009) has no explicit role of international trade and the only evidence on trade comes from the calibration of the key parameter using data from those open economies based on Sachs and Warner classification Sachs and Warner (1995). Hence we need a theory to explain why economic interactions can promote 
growth.

Lucas (2009) uses Sachs and Warner's classification which is subject to criticize. Rodriguez and Rodrik (2000) provides a critical survey on the literature of the impact of trade and growth. They argue that the findings on trade and growth are less robust than claimed. Moreover, the recent cross-sectional research confirm the criticisms of the Sachs-Warner findings by showing that the results are sensitive to the openness classification used in 1970-89 and do not hold for the 1990s. Another recent paper Wacziarg and Welch (2008) update the Sachs-Warner classification and results. They also address the critique of Rodriguez and Rodrik (2000). Hence we need to look at a more broad literature on the empirical findings of trade's impact on growth.

Before we build the model to study how trade can promote growth, we need to scrutinize some empirical findings about trade's impact on growth. There is a large empirical literature on the relationship between trade and growth. Here I will not exploit all the literature and I will only choose some important ones to establish the empirical fact that trade could promote growth. Frankel and Romer (1999) provides an empirical investigation of the impact of international trade on standards of living. In the empirical literature which study trade's impact on income, one difficulty of the OLS estimation is that the trade share may be endogenous. Hence the OLS estimation is not efficient and we need to control the problem of endogeneity. Frankel and Romer (1999) constructs measures of geographic component of countries' trade as instruments. They find no evidence that Ordinary least-squares estimates overstate the effects of trade 
on growth. Further, they find that trade has a quantitatively large and robust positive effect on income. Wacziarg and Welch (2008) also studies the effect of trade liberalization on growth. They provide some new evidence by updating Sachs-Warner's classification. Using new data set over 1950-98 period, countries that liberalized their trade regimes experienced average annual growth rate that were about 1.5 percentage point higher than before liberalization.

\section{Related Literature}

Eaton and Kortum (2001) develops a theoretical structure that unifies innovation, international trade and economic growth. We will follow this strand of research to consider trade and growth based on innovation. Baldwin and Robert-Nicoud (2008) explores the impact of trade on growth when firms are heterogeneous in productivity. They find that greater openness produces both anti- and pro-growth effect. They tried different endogenous growth models based on the variety expansion including Grossman-Helpman, the CoeHelpman, and the Rivera-Batiz-Romer Model. A closely related paper is Unel (2010) which considers the technology diffusion and trade. He integrates Melitz (2003) on trade and heterogeneous firms into the product innovation endogenous growth model developed by Romer (1990). He finds that exposure to trade can increase average productivity. However, the positive effects may not be high enough to cover the cost. Then his model like Baldwin and RobertNicoud (2008) produces an ambiguous result on trade and growth. Atkeson and Burstein (2010) develops a general equilibrium model of the decisions of firms to innovate and to engage trade. They find lower trade cost has a substantial 
effect on firms' decision of entry, exit, trade and innovation. However, they fail to find that reduction of trade cost has a substantial impact on aggregate productivity. Haruyama and Zhao (2008) also studies the effect of trade liberalization on the aggregate productivity and the growth of productivity in an R\&D based model with heterogeneous marginal cost for firms. Specifically, they use a quality-ladder model of growth to model the R\&D process. They argue that trade liberalization can increase the rate of technical progress as well as the level of manufacturing productivity.

We follow this paper to build our model by combining a creative destruction growth model developed by Aghion and Howitt (1992) and Melitz (2003). As in Haruyama and Zhao (2008), each innovation in my model is an improvement of the quality of the good. The engine of growth in my model is the continual improvement of quality of good. We use Aghion and Howitt (1992) and Grossman and Helpman (1991) to include creative destruction into the innovation process. That is, the prospect of more future research discourages current research since more future research reduces the rent accrued by current monopolist. The final product is produced using intermediate goods. Each intermediate good is produced by a monopolist. Firms which produce intermediate goods are heterogeneous in productivity level. Each firm who wants to enter the market has to make innovation to improve the quality of current goods. Firms pay fixed cost to make innovations and enter the market by replacing the incumbent. Then firms can pay a fixed cost to export to sell in the foreign market. Here I use Melitz (2003) to formalize the idea of international trade with heterogeneous 
firms. Then each intermediate good is associated with one productivity level as in Melitz (2003). I derive the balanced growth path of the economy and study how trade liberalization impacts the growth.

We find that trade liberalization can affect the cutoff value of productivity for firms to make innovation and export. That is, trade liberalization can help reallocate the labor to export behaviors of firms. Trade liberalization refers to the reduction of iceberg transportation cost and the reduction of sunk cost for export. We find that trade liberalization can make firms more likely to export. However, it also makes firms more difficult to make innovation and enter the domestic market. In this sense, trade liberalization drives the least productive firms out of the market. Hence it increases the average productivity of the economy. Trade liberalization can also help reallocate labor to do R\&D. The engine of growth is the improvement of quality through doing R\&D by firms. Hence the reallocation of labor to do $R \& D$ consequently increase the growth of the economy. We find that trade can indeed promote the growth of the economy.

The remaining of the paper is organized as follows. Section 2 presents the set up of the model. Section 3 analyzes the steady state equilibrium and solve for the balanced growth path. Section 4 studies the impact of trade liberalization. Section 5 concludes. Some of the derivations are gathered in the Appendix. 


\subsection{The Model}

We embed Melitz (2003) into a creative destruction model of endogenous growth Aghion and Howitt (1992) Specifically, we use Grossman and Helpman (1991) to model the innovation process. The engine of the growth for the economy is the improvement of the quality of goods. We use Erzo's formulation of quality ladders model as in Luttmer (2009).

\subsubsection{Consumer}

Time is continuous. Consumers derive utility from aggregate consumption. The consumer's problem is formulated as follows

$$
\begin{aligned}
& \max \int_{0}^{\infty} e^{-\rho t} \ln \left(C_{t}\right) d t \\
& \text { s.t. } \int_{0}^{\infty} \exp \left(-\int_{0}^{t} r_{s} d s\right) C_{t} d t \leq \text { wealth. }
\end{aligned}
$$

Solving this dynamic optimization problem leads to the usual first order condition for consumer

$$
\frac{\dot{C}_{t}}{C_{t}}=r_{t}-\rho
$$

$C_{t}$ is aggregate consumption which is a composite

$$
C_{t}=\exp \left(\int_{0}^{1} \ln \left(c_{t}(\omega)\right) d \omega\right)
$$

Each intermediate good comes in different vintages with different quality 
level. Let $S_{t}(\omega)$ be the number of the latest vintages which have been introduced at time $t$. Then we have

$$
c_{t}(\omega)=\sum_{n=0}^{S_{t}(\omega)} \lambda^{n} c_{n, t}(\omega) .
$$

\subsubsection{Producers}

The final good is produced using intermediate goods. Each intermediate good is produced by a monopolist by replacing the incumbent. The production of intermediate goods only require labor. Each firm produces an intermediate good. As in Melitz (2003), the production function for the owner of a blueprint for vintage $n$ of commodity $\omega$ can use one units of labor to produce $\varphi l$ units of the vintage. That is, $\lambda^{n} \varphi l$ in terms of date 0 units of commodity $\omega$. Assume that each firm has a different productivity level $\varphi$ and each good is associated with one productivity level. Hence we can index the goods using productivity level $\varphi$. All firms engage Bertrand competition. The frontier producer faces the competition from the second-best quality producer. The unit profit for the frontier producer is

$$
x_{t}(\varphi)=p_{t}(\varphi) \lambda^{S_{t}(\varphi)} \varphi-w_{t}
$$

The second-best producer's profit is

$$
p_{t}(\varphi) \lambda^{S_{t}(\varphi)-1} \varphi-w_{t}
$$

The frontier producer could shut down the second-best producer by setting 
price $p_{t}(\varphi)$ as

$$
p_{t}(\varphi)=\frac{w_{t}}{\lambda^{S_{t}(\varphi)-1} \varphi}
$$

Then the unit profit of the frontier producer is

$$
x_{t}(\varphi)=w_{t}(\lambda-1) .
$$

From the product market equilibrium, we can obtain the flow profit for the producer is

$$
\pi_{t}(\varphi)=\left(1-\frac{1}{\lambda}\right) C_{t} .
$$

If the firm exports to foreign countries, the flow profit from selling in the foreign market is

$$
\pi_{x t}(\varphi)=\left(1-\frac{\tau}{\lambda}\right) C_{t}
$$

where $\tau>1$ is the iceberg transportation cost.

\subsubsection{Innovations and Export Decisions}

To enter the market, firms have to make innovation to improve the quality of the good. To make innovations, firms have to incur sunk costs. Firms need to use some resources to do $\mathrm{R} \& \mathrm{D}$ and the resources cannot be recovered. In this sense, firms that do R\&D have to pay sunk costs. The R\&D cost for firms to make innovation by improving the quality of good is $f$. Let $v$ be the expected discounted value of flow profit in domestic market. If $v \geq f$, then firms will enter the domestic market by paying the sunk cost $f$ and become a monopolist. 
Therefore we can determine a cutoff value of productivity by

$$
v\left(\varphi_{*}\right)=f
$$

For firms to export, they need to a fixed cost $f_{x}$. Therefore firms export if $v_{x}(\varphi) \geq f_{x}$. Hence we can determine another cutoff value of productivity by

$$
v_{x}\left(\varphi_{x}\right)=f_{x}
$$

\subsubsection{Creative Destruction and Value of Firms}

The idea of creative destruction was first proposed by Schumpeter (1942). In growth models, creative destruction is referred to the replacement of incumbent by new entrants to improve the quality or the technology. Aghion and Howitt (1992) and Grossman and Helpman (1991) are two earlier examples of creative destruction growth models.

An entrant with a successful innovation can replace the incumbent in domestic market and earn the expected discounted value $v$ of flow profit. The new entrant will receive the exact profit as the incumbent who is replaced by the entrant. Hence $v(\varphi)$ has to follow the following equation

$$
r_{t} v_{t}(\varphi)=\pi_{t}(\varphi)+\dot{v}_{t}(\varphi)-\Gamma m_{t}(\varphi) v_{t}(\varphi)
$$

Here $\Gamma m_{t}$ is research effort exerted to improve the quality of good. This is the rate at which the incumbent will be replaced by a new entrant. This is also 
the term to measure the rate of creative destruction.

For firms who engage international trade with successful innovation, $v_{x t}$ can be obtained from serving the foreign market. Hence $v_{x t}$ will also follow a similar equation as follows

$$
r_{t} v_{x t}(\varphi)=\pi_{x t}(\varphi)+\dot{v}_{x t}(\varphi)-\Gamma m_{t}(\varphi) v_{x t}(\varphi)
$$

$v_{t}(\varphi)$ and $v_{x t}(\varphi)$ measure the expected discounted value of flow profit. Recall that firms have to pay sunk cost for both of making innovation and exporting. Therefore, the net value of innovation for a firm is given by

$$
V_{t}=\int_{\varphi_{*}}^{\infty}(v(\varphi)-f) \mu(\varphi) d \varphi+\int_{\varphi_{x}}^{\infty}\left(v_{x}(\varphi)-f_{x}\right) \mu(\varphi) d \varphi
$$

where $\mu(\varphi)$ is the distribution of productivity levels over $(0, \infty)$. The first term in the above equation gives the net value of making innovation and the second term measures the net value of additional gain from serving the foreign market.

\subsubsection{Labor Market}

There is no population growth in this model. The aggregate labor supply is $N_{t}=N 1^{1}$ Labor in this model has two purposes. One is to produce the final goods and the other purpose is to make innovation. Let $L_{t}$ denote the labor devoted to produce the final good and $M_{t}$ is used to make innovation. The labor

\footnotetext{
${ }^{1}$ However, we could include the population growth and this will not affect the result. See Haruyama and Zhao (2008), they consider a similar model with population growth to check the robustness of their model.
} 
market clearing condition is

$$
L_{t}+M_{t}=N
$$

Here we assume that the research effort is the same among all the industries. Therefore $m_{t}(\varphi)=M_{t}$ across all the industries.

\subsection{Steady State Equilibrium}

In this section, we analyze a steady state equilibrium for the model. First we derive the following conditions about the determination of cutoff values for productivity. The cutoff value for firms to enter the market $f$ is given by

$$
f=\frac{1}{\rho+\Gamma M_{t}}\left(1-\frac{1}{\lambda}\right) C_{t}(\varphi) .
$$

This equation is derived from eq. (9), (13). Similarly, we can derive an equation for the cutoff value of productivity for firms to export. The equation for $f_{x}$ is given by

$$
f_{x}=\frac{1}{\rho+\Gamma M_{t}}\left(1-\frac{\tau}{\lambda}\right) C_{t}(\varphi)
$$

These two equations help determine the cutoff values of productivity for firms to make innovation and export. The RHS of eq. (17) is the expected discounted flow profit of firms at the cutoff value of productivity $\varphi_{*}$. Therefore (17) can give us the cutoff value $\varphi_{*}$. Similarly, eq. (18) give us the cutoff value of productivity $\varphi_{x}$ for firms to export.

Remember, the aggregate consumption $C_{t}$ which appears on the RHS of (17) 
and (18) depends on the productivity level $\varphi \cdot C_{t}$ can be derived as

$$
C_{t}=\exp \left(\int_{0}^{1} \ln \left(\lambda^{S_{t}(\omega)}\right) d \omega\right) \frac{\varphi}{\lambda}\left(N+\frac{\rho}{\Gamma}\right)
$$

Substitute (19) into (17) and (18). Then we can determine the cutoff values.

Then we consider the R\&D decisions for firms. The second equilibrium condition is about the $R \& D$ decision. The expected value for firms to make innovation is given by

$$
\int_{\varphi_{*}}^{\infty}\left(1-\frac{1}{\lambda}\right) C_{t} \mu(\varphi) d \varphi+\int_{\varphi_{x}}^{\infty}\left(1-\frac{\tau}{\lambda}\right) C_{t} \frac{\phi(\varphi)}{1-\Phi\left(\varphi_{*}\right)} d \varphi
$$

The first term in the above equation is the expected flow profit from making innovation to enter the domestic market. The second term in the above equation measures the expected flow profit from export conditional on making innovation to enter the market by replacing the incumbent. The term $\phi(\varphi) /\left(1-\Phi\left(\varphi_{*}\right)\right)$ measures the conditional probability for a firm that has already entered the market by making innovation. Hence equation (20) gives the expected payoff from doing R\&D and make profit from serving both of domestic and foreign markets.

Recall that firms have to pay sunk costs to make innovation and export to sell in the foreign market. Therefore the expected sunk cost for firms to enter both of the domestic and foreign markets is given by

$$
f+f_{x} \frac{\phi(\varphi)}{1-\Phi\left(\varphi_{*}\right)}
$$


Still, here we need to consider the conditional probability of firms to export after making innovation to sell in the domestic market. To obtain an equilibrium, the expected flow profit from making innovations and export must be equal to the expected sunk costs of making innovation and export. The two terms on the RHS represent the expected cost from making innovation and export. Hence we obtain the following equilibrium condition

$$
\int_{\varphi_{*}}^{\infty}\left(1-\frac{1}{\lambda}\right) C_{t} \mu(\varphi) d \varphi+\int_{\varphi_{x}}^{\infty}\left(1-\frac{\tau}{\lambda}\right) C_{t} \frac{\phi(\varphi)}{1-\Phi\left(\varphi_{*}\right)} d \varphi=f+f_{x} \frac{\phi(\varphi)}{1-\Phi\left(\varphi_{*}\right)}
$$

The last equilibrium condition comes from the labor market clearing condition which we have discussed in the last section. This equilibrium condition is given by equation (16) .

Now we can determine a balanced growth path of the model. Remember the engine of growth in this model is the continual improvements of quality for goods. Given the structure of the aggregate consumption as in equation (19), we can determine the balanced growth rate of the economy based on the arrival of improvement of quality.

Following Luttmer (2009), we assume that the number of vintages follows a Poisson distribution with the density as given by

$$
f_{t}(s)=\frac{(\theta t)^{s} e^{-\theta t}}{s !} \text {. }
$$


Also we assume Law of Large Number holds. Then we can obtain that

$$
\int_{0}^{1} \ln \left(\lambda^{S_{t}(\omega)}\right) d \omega=\ln (\lambda) \int_{0}^{1} S_{t}(\omega) d \omega=\ln \sum_{s=0}^{\infty} s f_{t}(s)=\theta \ln (\lambda) t
$$

Hence the growth rate of economy is $\theta \ln (\lambda)$ and $\theta$ is the arrival rate of improvement of quality. In this model, $\theta$ is $\Gamma M_{t}$. The growth rate of the economy depends on the $R \& D$ efforts measured by the workers allocated to $R \& D$ sector.

We summarize the result in the following proposition.

Proposition 3 The growth rate of the economy is given by $\Gamma M_{t} \ln (\lambda)$.

\subsection{The Impact of Trade}

In this section, we study how trade liberalization can affect the growth of the economy. We try to explore the implications for growth models with creative destruction features in open economy.

First, we consider the effect of trade liberalization on the cutoff values of productivity. From eqs. (17) and (18), we can obtain the following relationship between two cutoff values $\varphi_{*}$ and $\varphi_{x}$

$$
\frac{\varphi_{*}}{f}=\frac{\lambda-\tau}{\lambda-1} \frac{\varphi_{x}}{f_{x}} .
$$

Trade liberalization refers to the reduction of sunk cost for export and the reduction of iceberg transportation cost. We first consider the effect of reduction of sunk cost for export i.e., $f_{x}$ on the threshold of productivity value $\varphi_{x}$. Ceteris 
Paribus, a reduction of sunk cost for exporting $f_{x}$ reduces the cutoff value of productivity for firms to export i.e., $\varphi_{x}$ decreases. This make firms be easier to become exporters and also reallocate the resources from non-exporting sectors to exporting sectors. This is consistent with the standard literature as Melitz (2003).

On the other hand, we will consider the effect of trade liberalization on the cutoff value for firms to make innovation and enter the domestic market. Also from equation (25), we fix the value of $f_{x}$ and hence the value of $\varphi_{x}$. A reduction of iceberg transportation cost $\tau$ will increase the value of RHS of equation (25). Hence $\varphi_{*}$ has to increase. The increase of cutoff value of productivity $\varphi_{*}$ will make firms more difficult to make innovation. In turn, this makes firms be more difficult to enter the domestic market. Therefore, the less productive firms will be driven out of the market and replaced by more productive firms. On average, this can also increase the average productivity level for the economy. These results are summarized in the following proposition.

Proposition 4 The effect of trade liberalization makes firms more likely to export and also makes firms more difficult to make innovations and hence more difficult to enter the domestic market.

Then we want to consider the effect of trade liberalization on the innovation behaviors of the firms. We have seen that reduction of trade barriers can decrease the cutoff value for export $\varphi_{x}$ and increase the cutoff value for making innovation $\varphi_{*}$. 
In our model, the innovation is done by labor that is devoted to do R\&D. We will consider how reduction of transportation cost $\tau$ can affect the allocation of labor in R\&D activities. We are also interested in the effect of a decrease of sunk cost for firms to export on the allocation of labor in R\&D activities. We can obtain the following equality based on equation (22)

$$
\left(\rho+\Gamma M_{t}\right)\left\{f \int_{\varphi_{*}}^{\infty} \mu(\varphi) d \varphi+f_{x} \int_{\varphi_{x}}^{\infty} \frac{\phi(\varphi)}{1-\Phi\left(\varphi_{*}\right)} d \varphi\right\}=f+f_{x} \frac{\phi(\varphi)}{1-\Phi\left(\varphi_{*}\right)}
$$

The derivation of this equality is included in the Appendix.

First, we consider the effect of a reduction of the iceberg transportation cost $\tau$. Remember that a reduction of the iceberg transportation cost $\tau$ leads to the increase of cutoff value $\varphi_{*}$ for firms to make innovation and enter the domestic market. This can be seen from equation (25). If we assume that the productivity is drawn from a Pareto distribution, then we can know that the term $\int_{\varphi_{*}}^{\infty} f \mu(\varphi) d \varphi$ decreases due to the rise of cutoff value $\varphi_{*}$. To keep the equality of (26), $M_{t}$ must be increased. That is, the labor allocated to do R\&D must increase. A reduction of transportation cost can increase the cutoff value for firms to enter domestic market. Less productive firms will be driven out of the market. From equation (26), the rise of cutoff value $\varphi_{*}$ will increase the RHS of (26) . To cover the increase of ex ante sunk cost for entry, the firms have to hire more labor to work in R\&D.

Then, we consider the effect of a reduction of the sunk cost for export. If $f_{x}$ decreases, then the cutoff value $\varphi_{x}$ for firms to export also decreases. This will also increase the probability for firms to export. Since $\phi(\varphi) /\left[1-\Phi\left(\varphi_{*}\right)\right]$ 
measures the probability for firms to export conditional on making the innovation. This probability must increase. Then the magnitude of increase of the second term on RHS must outweigh the term $f_{x} \int_{\varphi_{x}}^{\infty} \frac{\phi(\varphi)}{1-\Phi\left(\varphi_{*}\right)} d \varphi$ on LHS. To keep the equality, $M_{t}$ has also to rise. Therefore, the labor allocated to making innovation increases. That is, a reduction of sunk cost for export can also increase the labor to do R\&D.

Hence, the trade liberalization we have considered can unambiguously increase the labor allocated to the R\&D. We summarize the results in the following proposition.

Proposition 5 Trade liberalization we considered here refers to the reduction of iceberg transportation cost and the sunk cost for export. We find that trade liberalization can increase the allocation of labor to do R\&D.

Finally, we need to consider the impact of trade on the productivity growth of the economy. Recall that the engine of the growth of this economy comes from the improvements of quality. To improve the quality of goods, firms have to use labor to do R\&D. Since we have shown that the trade liberalization can allocate more labor to do R\&D, we can know that trade liberalization can indeed promote the growth in this economy. This is our fundamental results of our paper. This makes sharp contrast with Baldwin and Robert-Nicoud (2008) and Unel (2010) in which they find the ambiguous results of trade impact on growth. However, we use different type of models to model the growth of the economy. We summarize the result in the following proposition. 
Proposition 6 Trade liberalization as defined in Proposition 3 can unambiguously promote the growth of the economy.

\subsection{Concluding Remarks}

In this paper, we embed Melitz (2003) model of trade with heterogeneous firms into an endogenous growth model. We want to study the impact of trade on growth. We find that trade has a big impact on the reallocation of labor to R\&D activities. We study two types of trade liberalization i.e., reduction of iceberg transportation cost and reduction of sunk cost for export. We find that trade liberalization can reallocate labor resources to the exporting firms. This reallocation drives the least productive firms to exit the market and therefore increase the average the productivity. Since this reallocation increases the labor to do R\&D, trade liberalization also increases the growth of this economy. We find that trade can promote growth in the long run.

The present work can be extended in several ways. Here I consider the growth in a creative destruction model as studied in Grossman and Helpman (1991). In this type of model, only the entrant can make innovation and enter the market by replacing the incumbent. However, we could also allow the incumbent to make innovation using the current blueprint. This kind of creative destruction growth model is studied in Klette and Kortum (2004). In their model, the incumbent will use labor to make improvement. This will make our model more realistic. 
Another extension could be made by studying multi-sector model of Grossman and Helpman (1991) and also may add capital into the production. However, this may make the model more complicated and maybe beyond being tractable.

There are also some limits of our paper. First, we do not include the welfare analysis. Further research should be done to check whether exposure to trade can increase the welfare of consumers. Also this paper is a qualitative one. Further research should be devoted to explore the quantitative implications of the paper. 


\section{Chapter 4}

\section{Structural Change and Economic Development: A Revisit}

\subsection{Introduction}

In this chapter, I review the recent development in structural change and the implications for economic development. Most countries undergo a process of structural transformation during economic development. For many developing countries, economic development has been fundamentally uneven among different sectors in the economy. For instance, China first began to develop in tradable sectors and then other sectors. Labor-intensive sectors start to grow earlier than other sectors in China along the development path.

Lewis (1954) first argues that labor reallocation from agricultural sector to manufacturing sector provides sufficient labor resource for industrial production. 
Most countries have experienced substantial amounts of labor reallocation from agricultural sector to manufacturing sector and service sector. As documented in Duarte and Restuccia (2010), the share of hours in agriculture in Spain fell from $44 \%$ to $6 \%$ from 1966 to 2004. The share of hours in agriculture in Belgium fell from $7 \%$ to $2 \%$.

Recently, theoretical research on economic growth has included the phenomenon of structural change in standard models of economic growth. Traditional models of economic growth focus on the balanced growth path solutions which characterize the long run behavior of the U.S. economy. Balanced growth models are consistent with Kaldor facts which are a collection of stylized facts of economic growth in the U.S. over the long run. Kaldor facts summarize that the growth rate of output, the capital-output ratio, the real interest rate, and the labor income share are all roughly constant over time. However, economic growth takes place at uneven rates across different sectors of the economy. It is also an important fact that labor is reallocated from agricultural sector to the manufacturing sector over time for most of countries. This uneven growth pattern is also very important to understand the economic development as emphasized in a recent paper Ray (2010).

The structural change arises as an economy becomes richer. In theory, this structural change can be induced by demand side or supply side. Nonhomothetic preference can generate uneven growth for agricultural sector and manufacturing sector or service sector. As a country becomes richer, consumers demand less agricultural good and consume more manufacturing good. This is 
the so-called Engel's Law. A recent paper Kongsamut, Rebelo, and Xie (2001) follows this line of research. They impose a subsistence level of agricultural consumption or food requirement in the utility function. Without satisfying the subsistence level of food requirement, the consumer cannot survive and the utility function is not well defined. As the food requirement is satisfied, the consumer starts to consume manufacturing good and service good. The other reason for nonbalanced growth is technology related. This line of research is first proposed by Baumol (1967) and recently studied in Ngai and Pissarides (2007). In this line of research, structural change follows from the different growth rate of productivity in various sectors of an economy.

The rest of this chapter is organized as follows. Section 2 and Section 3 examine the supply side and demand side analysis of structural change. Section 4 discusses the implications for economic development and studies some applications of the framework of structural change. Section 5 discusses the structural change in an open economy setup and some relevant development issues. Section 6 concludes.

\subsection{An Illustrative Model}

Baumol (1967) first considers the situation that different sectors exhibit different growth rate of productivity. Following Baumol (1967), we present a simple model that shows the uneven expansion of two sectors. According to Baumol's 
paper, the economy is divided into two sectors. One is technologically progressive sector and the other is stagnant sector which has no productivity growth over time. The uneven growth between the two sectors arises from the uneven productivity growth.

\subsubsection{The Model}

Assume there are two sectors in the economy. The output for these two sectors are $Y_{1 t}$ and $Y_{2 t}$ at time $t$ :

$$
\begin{aligned}
& Y_{1 t}=a L_{1 t}, \\
& Y_{2 t}=b e^{r t} L_{2 t}
\end{aligned}
$$

where $L_{1 t}$ and $L_{2 t}$ are labor allocation into the two sectors and $a$ and $b$ are constants.

The productivity levels of these two sectors follow from the production function and are given by

$$
\begin{aligned}
& \frac{Y_{1 t}}{L_{1 t}}=a \\
& \frac{Y_{2 t}}{L_{2 t}}=b e^{r t} .
\end{aligned}
$$

In this sense, we call Sector 1 is "stagnant" sector and Sector 2 is "progressive" sector. It follows the fact that the productivity in Sector 1 is constant over time and the productivity in Sector 2 is growing over time. 
Wages are equal to marginal product of labor and we assume both sectors have the same wage. The wage is given by

$$
w_{t}=w e^{r t}
$$

where $w$ is a constant.

The cost of per unit of output of sector 1 and sector 2 are $C_{1}$ and $C_{2}$

$$
\begin{aligned}
& C_{1}=\frac{w_{t} L_{1 t}}{Y_{1 t}}=\frac{w e^{r t}}{a}, \\
& C_{2}=\frac{w_{t} L_{2 t}}{Y_{2 t}}=\frac{w}{b} .
\end{aligned}
$$

The relative costs between these two sectors are given by

$$
\frac{C_{1}}{C_{2}}=\frac{b e^{r t}}{a}
$$

From the above equation, we can see that the relative cost of sector 1 is ever increasing over time. We could expect that the demand for the output of sector 1 would decline.

The relative output between these two sectors is given by

$$
\frac{Y_{1}}{Y_{2}}=\frac{a L_{1 t}}{b L_{2 t} e^{r t}}=\frac{R}{e^{r t}}
$$

where $R$ is a constant.

From the relative output ratio, we can see that the output of stagnant sector 
1 will decline to zero over time.

To see how structural change happens in this model, we need to solve for the labor reallocation between these two sectors. To obtain a solution for the labor allocation, we further maintain an assumption that the output ratio between these two sectors is constant.

$$
\frac{b}{a} \frac{Y_{1}}{Y_{2}}=\frac{L_{1}}{L_{2} e^{r t}}=K
$$

Let $L$ be the total labor supply and $L$ is divided in the two sectors. It follows that

$$
\begin{aligned}
L_{1} & =\frac{L K e^{r t}}{1+K e^{r t}}, \\
L_{2} & =\frac{L}{1+K e^{r t}} .
\end{aligned}
$$

From the above equation, we can see that labor is reallocated to the stagnant sector 1 over time. This is the process of structural change. A recent paper Ngai and Pissarides (2007) explores along this line of research in a multisector growth model.

\subsection{Structural Change: Demand Side Analysis}

The other reason for structural change is the nonhomothetic preference. In this section, we study a simple static model with a nonhomothetic preference to show the occurrence of structural change from the demand structure of the 
economy.

\subsubsection{The Model}

We abstract from intertemporal decisions and employ a static model for illustration of the mechanism. Here we consider two sectors: agricultural sector and manufacturing sector. We employ a nonhomothetic preference for consumption of agricultural sector. The model setup is as follows.

\subsubsection{The Setup}

In this simple model, we consider a model in which the household makes a static decision over consumption of two goods: agricultural good and manufacturing good. The household has a nonhomothetic preference over these two goods and features a subsistence level of consumption of agricultural good. The preference of the household is given by

$$
u\left(c_{a}, c_{m}\right)=a \log \left(c_{a}-\bar{a}\right)+(1-a) \log \left(c_{m}\right)
$$

The household's problem is to maximize the utility subject to the budget constraint. It is specified as follows

$$
\begin{aligned}
& \max u\left(c_{a}, c_{m}\right) \\
& \text { subject to } \\
& p_{a} c_{a}+p_{m} c_{m}=w L .
\end{aligned}
$$


where $p_{a}, p_{m}$ are prices for agricultural good and manufacturing good respectively, $w$ is the wage and $L$ is the total labor supply.

Firm in this economy uses only labor to produce final output in each sector. The production function for each sector is given by

$$
Y_{i}=A_{i} L_{i}, \quad i \in\{a, m\}
$$

where $A$ is the productivity level in each sector respectively.

\subsubsection{Equilibrium}

The competitive equilibrium of this economy is a set of prices $\left\{p_{a}, p_{m}\right\}$, allocations of consumption $\left\{c_{a}, c_{m}\right\}$, an allocation of labor $\left\{L_{a}, L_{m}\right\}$ such that $(i)$ given prices, the household solves the problem given above, $(i i)$ firms maximize their profits, and $(i i i)$ the following market clearing conditions hold.

- Goods market clears

$$
\begin{aligned}
c_{a} & =Y_{a} \\
c_{m} & =Y_{m} .
\end{aligned}
$$

- Labor market clears

$$
L_{a}+L_{m}=L
$$

where $L$ is the total labor and assumed to be a constant. 
From the household's problem, we can obtain that

$$
\frac{c_{m}}{c_{a}-\bar{a}}=\frac{1-a}{a} \frac{p_{a}}{p_{m}} .
$$

From firms' problem, we can obtain the price for each good

$$
p_{i}=\frac{1}{A_{i}}, \quad i \in\{a, m\} .
$$

Hence we can solve for the labor allocation in each sector. The labor allocation in agricultural sector is given by

$$
L_{a}=(1-a) \frac{\bar{a}}{A_{a}}+a L .
$$

From the above equation, we can see that the labor allocation in the agricultural sector depends on the subsistence level consumption of agricultural good and the productivity level of agricultural production technology. To satisfy the food requirement, there must be sufficient labor to be allocated in the agricultural sector. The labor allocation in agricultural sector is negatively related with the productivity of agricultural sector. If there is an improvement in the productivity of agriculture, the labor is reallocated to the manufacturing sector. As an economy develops, the food requirement is relaxed. Hence labor can be released to the manufacturing sector. This is the mechanism of structural change driven by demand side. 


\subsection{Dynamic Models}

In this section, we review the recent studies of growth models that include structural change. Traditional growth models are created to be consistent with Kaldor facts. However, there is massive sectoral reallocation of labor by all expanding economies. Typically, this observation is ignored by the growth literature which only focuses on the balanced growth path.

\subsubsection{A Dynamic three-sector Model}

A recent paper Kongsamut, Rebelo, and Xie (2001) studies extends a traditional growth model to capture the Kuznets facts. This is a dynamic version of the model with nonhomothetic preferences in previous section. They build a threesector model including agriculture, manufacturing, and service sectors with a nonhomothetic preference to capture the massive reallocation of labor from agriculture to service sector as an economy expands. We review the basic setup and discusses the implications of the model in this subsection.

The sectoral movements of labor originate from differences in the income elasticity of demand for the different goods. They employ a Stone-Geary preference structure to capture the different income elasticity of demand for different goods. The preference structure is given by

$$
U=\int_{0}^{\infty} e^{-\rho t} \frac{\left[\left(A_{t}-\bar{A}\right)^{\beta} M_{t}^{\gamma}\left(S_{t}+\bar{S}\right)^{\theta}\right]^{1-\sigma}-1}{1-\sigma} d t
$$

These preferences imply that income elasticity of demand is less than one for 
agricultural goods, equal to one for manufacturing goods, and greater than one for services. The variable $\bar{A}$ can be interpreted as the level of subsistence consumption for agricultural goods, and $\bar{S}$ represents the home production of services.

The production structure of the economy is to use two factors of production, capital $\left(K_{t}\right)$ and labor. Assume that the total labor is normalized to be one in the economy at every point in time. The production structure is defined as follows.

$$
\begin{aligned}
A_{t} & =B_{A} F\left(\phi_{t}^{A} K_{t}, N_{t}^{A} X_{t}\right), \\
M_{t}+\dot{K}_{t}+\delta K_{t} & =B_{M} F\left(\phi_{t}^{M} K_{t}, N_{t}^{M} X_{t}\right), \\
S_{t} & =B_{S} F\left(\phi_{t}^{S} K_{t}, N_{t}^{S} X_{t}\right), \\
\phi_{t}^{A}+\phi_{t}^{M}+\phi_{t}^{S} & =1, \\
N_{t}^{A}+N_{t}^{M}+N_{t}^{S} & =1, \\
\dot{X}_{t} & =X_{t} g, \\
K_{0}, X_{0}>0, \text { given. } &
\end{aligned}
$$

The complete solutions to the model and the detailed characterization of the equilibrium of this model is referred to the original paper. Here I consider one special generalized balanced growth path as defined in the original paper. Under some condition $\mathrm{S}^{1}$ derived in the original paper, there exists a generalized

\footnotetext{
${ }^{1}$ The condition is specified as $\bar{A} B_{S}=\bar{S} B_{A}$.
} 
balanced growth path. The generalized balanced growth path in this model is defined as the trajectory along which real interest rate is constant ${ }^{2}$. The structural change happens in this economy along this generalized balanced growth path. The following conditions show the growth of employment in the three sectors.

$$
\begin{aligned}
\dot{N}_{t}^{A} & =-g \frac{\bar{A}}{B_{A} X_{t} F(k, 1)} \\
\dot{N}_{t}^{M} & =0 \\
\dot{N}_{t}^{S} & =g \frac{\bar{S}}{B_{S} X_{t} F(k, 1)}
\end{aligned}
$$

From the above equations, we can see that the model discussed here generates the structural change which is consistent with the massive reallocation of labor across sectors. The share of labor in agriculture declines, while the share of labor in services expands. Also this model will converge to the standard balanced growth path as the importance of $\bar{A}$ and $\bar{S}$ declines with the expanding of the economy.

\subsubsection{A Dynamic Multisector Model}

In another paper Ngai and Pissarides (2007), they approach the problem of structural change in another way by exploring the implications of the different sectoral total factor productivity (TFP). They follow the idea originated in

\footnotetext{
${ }^{2}$ The balanced growth path in standard growth models is defined as the constancy of growth rate of output
} 
Baumol (1967). They consider a model with many consumption goods and a single capital good produced by manufacturing sector. The basic setup of the model is discussed as follows.

$$
U=\int_{0}^{\infty} e^{-\rho t} v\left(c_{1}, \ldots, c_{m}\right) d t
$$

The production structure is discussed as follows. The resource constraints in this economy are given by

$$
\begin{aligned}
c_{i} & =F^{i}\left(n_{i} k_{i}, n_{i}\right) \forall i \neq m ; \\
\dot{k} & =F^{m}\left(n_{m} k_{m}, n_{m}\right)-c_{m}-(\delta+\nu) k,
\end{aligned}
$$

The production function is given by as follows and assume rate of TFP growth is different in each sector.

$$
F^{i}=A_{i} F\left(n_{i} k_{i}, n_{i}\right) ; \dot{A}_{i} / A_{i}=\gamma_{i} ; \forall i
$$

Based on this model, they find that the growth rate of two sectors' relative employment depends only on the difference between the sectors' TFP growth rates and the elasticity of substitution between goods. They define structural change as the state in which at least one sector's labor share is changing over time. The key equations that govern employment shares are given by 


$$
\begin{aligned}
n_{i} & =\frac{x_{i}}{X}\left(\frac{c}{y}\right) \forall i \neq m, \\
n_{m} & =\frac{x_{m}}{X}\left(\frac{c}{y}\right)+\left(1-\frac{c}{y}\right) .
\end{aligned}
$$

The dynamics of these employment shares are given by

$$
\begin{aligned}
\frac{\dot{n}_{i}}{n_{i}} & =\frac{(\dot{\overline{c / y}})}{c / y}+(1-\varepsilon)\left(\bar{\gamma}-\gamma_{i}\right) ; \forall i \neq m ; \\
\frac{\dot{n}_{m}}{n_{m}} & =\left[\frac{\dot{(\overline{c / y}}}{c / y}+(1-\varepsilon)\left(\bar{\gamma}-\gamma_{m}\right)\right] \times \frac{(c / y)\left(x_{m} / X\right)}{n_{m}}+\left(\frac{-(\dot{c / y})}{1-c / y}\right)\left(\frac{1-c / y}{n_{m}}(4) .42\right)
\end{aligned}
$$

These two equations drive the main result of structural change. The framework is robust to including intermediate goods and many capital goods. In both cases, this model can still predict the structural change.

\subsection{Implications for Economic Development}

In this section, we examine the literature on the implications of structural change for economic development. For most developing countries, the economy does not grow evenly and structural change is a key feature along the development path of the economy. The framework of structural change is widely used to understand development issues such as the large variations in productivity across countries. 
In the previous section, we review a model of structural change arising from the nonhomothetic preference. The feature of the model is the emphasis on the food requirement. Developing countries are less productive in agricultural sector and therefore need to allocate sufficient labor resource in the agricultural sector to produce the subsistence level of food. The difference in productivity in agricultural sector across countries provides us with a perspective to understand the large variations in productivity across countries. Restuccia, Yang, and Zhu (2008) explores this line of research. They find that a high share of employment and low labor productivity in agriculture are mainly responsible for low aggregate productivity in poor countries. They use a two-sector neoclassical growth model with a nonhomothetic preference to study this phenomenon quantitatively. They also find the two-sector model performs better than a single sector model in quantitative sense to account for the difference in productivity.

This kind of food problem in poor countries was first raised by Schultz (1953). Many poor countries suffer from food problem and this is a drag for economic development for these poor countries. Without satisfying the subsistence need of food, one country cannot begin to develop its industrial economy. The growth models with structural change provides an appropriate framework to study the international income evolution. This framework can explain why some countries started to grow far behind advanced countries in history. Also an improvement in productivity of agriculture can potentially generate a growth miracle such as the East Asia Miracle. This is shown in Gollin, Parente, and 
Rogerson (2007) by employing a one-sector growth model with food requirement in preference. They find the food problem is quantitatively important to explain the international income evolution. It is the first step to improve the efficiency of agricultural sector for developing countries to ignite the industrial development.

The structural change is not only a simple process of labor reallocation. It is also a process of improvement of aggregate productivity. In addition to the variations in income levels across countries, there is also a large difference in productivity across countries. Structural change plays an important role of accounting for the variations in productivity. A recent paper Duarte and Restuccia (2010) finds that productivity gaps have been substantially reduced in agriculture and industry, but not nearly as much in services. The labor reallocation from less productive sector to the more productive sector associated with the structural change has improved the aggregate productivity substantially in developing countries. The reallocation of labor from less productive agricultural sector to the more productive manufacturing sector provides a large pool of labor for industrial development. This is the basis for China's comparative advantage. The structural change ignited the fast growth of Chinese economy.

The structural change can also be applied to study the regional convergence in developed countries. Within a single country, different regions may experience different level of development. As shown in Caselli and Coleman II (2001), there is nationwide convergence of agricultural wages to nonagricultural wages and the fast transition of the southern labor force from agricultural to nonagricultural 
jobs. This phenomenon can be explained by the role of structural change of the U.S. economy. With declining costs of acquiring nonfarming skills, it is easier for people to learn the nonfarming skills so that they can move to work in other sectors of the economy. With the fast growing of productivity in agriculture, more people can move out of the agriculture. The interaction of these two effects move more people out of the agriculture and convergence occurs between north and south of the U.S. economy.

The framework of structural change can help us understand a wide range of development issues. Traditionally, most literature considers the structural change in a closed economy setup as we discussed in the previous sections of this chapter. With the increasing globalization, the uneven growth is strengthened. In the next section, we review the effect of globalization on the structural change.

\subsection{Globalization and Structural Change}

Increased opening to the world economy enhances the uneven growth at the country level. The sectors with comparative advantages will grow faster than other sectors once the country opens to the world economy. For instance, China traditionally makes heavy investment in the heavy industry following USSR's development model before China adopts the open door policy and opens its economy to the world. Since 1978, China begins to adopt the open door policy and opens its economy to the world economy. The production pattern for Chinese economy has changed dramatically. Chinese economy now specializes 
in production of labor intensive commodities and export them to the rest of the world. With further exploration of comparative advantage, Chinese economy started to takeoff since the year of 1978 .

Pioneered by Matsuyama (1992) and Matsuyama (2009), theoretical research of structural change has been extended to open economy setup. With the international trade, the process of structural change can be accelerated. For poor countries, they can import the agricultural good to satisfy their food requirement instead of improving the productivity in agriculture substantially to produce enough food. With the exploration of comparative advantage, developing countries can choose to import the goods which domestic country is not productive to produce. By importing, domestic country can release labor to other sectors in which it has a comparative advantage. Following this development strategy, developing countries only need to focus on its own comparative advantage. With the increase of the income along the development path, there is a change in the demand structure due to the property of nonhomothetic preferences. This change of demand structure brings the structural change in the economy as shown by the aforementioned theoretical models. This process of structural change helps the economy reallocate its resources and improve the aggregate productivity.

A recent development in the theory of structural change in open economy is studied in Yi and Zhang (2011). They develop a tractable three-sector model in a two-country world. Their model is built on Ngai and Pissarides (2007) and Eaton and Kortum (2002). The model has one factor of production, three 
sectors: agriculture, manufacturing, and services sector. Both agricultural and manufacturing sectors are tradable sectors and services sector is nontradable. To highlight the international trade, the international trade is introduced into the model in a Ricardian type à la Eaton and Kortum (2002). The key parameters that govern the sectoral labor allocations are those governing productivity, trade cost, and the elasticity of substitution between sectors. In an open economy, each sector's employment share is the sum of the share of domestic expenditures on that sector and the net export share of total GDP. Since the employment share depends on net export share, comparative advantage determines the specialization and therefore impacts the structural change. This is the direct contribution of international trade to sectoral labor allocation. There is also an indirect contribution of openness to the structural change. Since relative prices are different in an open economy from autarky, expenditure shares will also be affected by openness. After international trade, domestic price can be lowered for some traded goods and price will be lower for that sector than autarky. If the elasticity of substitution is less than one, this sector will experience a lower expenditure share hence a lower employment share. This is the mechanism of structural change in this model.

\subsection{Concluding Remarks}

For developing countries, uneven growth is usually a feature for economic development. Most developing countries start economic development in one sector 
and then another. Traditionally, developing countries start industrialization by reallocating people from agriculture to manufacturing to provide sufficient workers in factories. In a time of globalization, countries usually start to grow in the sector in which they have a comparative advantage. To fully understand the economic development, one must include the structural change into the standard economic growth models which usually features the balanced growth path. Growth models with structural change provides a very useful framework to understand a wide range of issues in developing countries along their development paths.

The mechanism of structural change in theoretical model helps us figure out one development strategy. Developing countries can ignite economic development from the one sector in which they have comparative advantage and then spread to other sectors. With the increase of income, change of demand structure will help change the production pattern by reallocating resources and improve the aggregate productivity. 


\section{References}

Aghion, P., And P. Howitt (1992): "A Model of Growth Through Creative Destruction," Econometrica, 60, 323-351.

Atkeson, A., and A. Burstein (2010): "Innovation, Firm Dynamics, and International Trade," Journal of Political Economy, 118(3), 433-484.

Bajona, C., and T. Chu (2010): "Reforming State Owned Enterprises in China: Effects of WTO Accession," Review of Economic Dynamics, 13, 800823.

Baldwin, R. E., And F. Robert-Nicoud (2008): "Trade and Growth with Heterogeneous Firms," Journal of International Economics, 74, 21-34.

Baumol, W. J. (1967): "Macroeconomics of Unbalanced Growth: The Anatomy of Urban Crisis," American Economic Review, 57(3), 415-426.

Brant, L., C.-T. Hsieh, and X. Zhu (2008): "Growth and Structural Transformation in China," in China's Great Economic Transformation, ed. by L. Brandt, and T. Rawski, pp. 569-632. Cambridge University Press. 
Brant, L., And X. Zhu (2010): “Accounting for China's Growth," IZA Discussion Paper No. 4764.

Caselli, F., and W. J. Coleman II (2001): "The U.S. Structural Transformation and Regional Convergence: A Reinterpretation," Journal of Political Economy, 109(3), 584-616.

Connolly, M., and K.-M. Yi (2009): "How Much of South Koreas Growth Miracle Can Be Explained by Trade Policy?," Federal Reserve Bank of Philadelphia Working Paper 09-19.

Dekle, R., And G. Vandenbroucke (2006): "A Quantitative Analysis of China's Structural Transformation," Federal Reserve Bank of San Francisco Working Paper no. 2006-37.

Duarte, M., And D. Restuccia (2010): "The Role of the Structural Transformation in Aggregate Productivity," Quarterly Journal of Economics, $125(1), 129-173$.

Eaton, J., And S. Kortum (2001): "Technology, Trade, and Growth: A Unified Framework," European Economic Review, 45, 742-55.

(2002): “Technology, Geography, and Trade," Econometrica, 70(5), $1741-1779$.

Frankel, J. A., And D. Romer (1999): "Does Trade Cause Growth?," American Economic Review, June, 379-99. 
Gollin, D., S. L. Parente, and R. Rogerson (2007): "The Food Problem and the Evolution of International Income Levels," Journal of Monetary Economics, 54, 1230-1255.

Grossman, G. M., and E. Helpman (1991): Innovation and Growth in the Global Economy. MIT Press.

Haruyama, T., And L. Zhao (2008): "Trade and Firm Heterogeneity in a Quality-Ladder Model of Growth," working paper.

Hayashi, F., And E. C. Prescott (2008): "The Depressing Effect of Agricultural Institutions on the Prewar Japanese Economy," Journal of Political Economy, 116(4), 573-632.

HsieH, C.-T., And P. J. Klenow (2009): "Misallocation and Manufacturing TFP in China and India," Quarterly Journal of Economics, CXXIV, 14031448.

Jones, C. I. (2010): "Misallocation, Economic Growth, and Input-Output Economics," unpublished manuscript.

- (2011): "Intermediate Goods and Weak Links in the Theory of Economic Development," American Economic Journal: Macroeconomics, 3(2), $1-28$.

Kenoe, T. J., And K. J. Ruhl (2009): "Sudden Stops, Sectoral Reallocations, and the Real Exchange Rate," Journal of Development Economics, 89, 23549. 
(2010): "Why Have Economic Reforms in Mexico Not Generated Growth?," Journal of Economic Literature, 48(4), 1005-27.

Klette, T. J., And S. Kortum (2004): "Innovating Firms and Aggregate Innovation," Journal of Political Economy, 112, 986-1018.

Kongsamut, P., S. Rebelo, And D. Xie (2001): "Beyond Balanced Growth," Review of Economic Studies, 68(4), 869-882.

Koopman, R., Z. Wang, and S.-J. Wei (2008): "How Much of Chinese Exports is Really Made in China? Assessing Domestic Value-Added When Processing Trade is Pervasive," NBER Working Paper no. 14109.

LEwis, W. A. (1954): "Economic Development with Unlimited Supplies of Labor," Manchester School of Economic and Social Studies, 22, 139-191.

Linden, G., K. L. Kraemer, and J. Dedrick (2009): "Who Captures Value in a Global Innovation Network? The Case of Apple's iPod," Communications of the ACM, 52(3), 140-144.

LuCAS, R. E. (2009): "Trade and the Diffusion of the Industrial Revolution," American Economic Journal: Macroeconomics, 1, 1-25.

Luttmer, E. G. J. (2009): "Quality Ladders," Lecture notes, University of Minnesota.

Matsuyama, K. (1992): "Agricultural Productivity, Comparative Advantage and Economic Growth," Journal of Economic Theory, 58, 317-334. 
(2009): "Structural Change in an Interdependent World: A Global View of Manufacturing Decline," Journal of the European Economic Association, 7(2-3), 478-486.

Melitz, M. J. (2003): "The Impact of Trade on Intra-Industry Reallocations and Aggregate Industry Productivity," Econometrica, 71, 1695-1725.

Ngai, L. R., And C. A. Pissarides (2007): "Structural Change in a Multisector Model of Growth," American Economic Review, 97(1), 429-443.

RAY, D. (2010): "Uneven Growth: A Framework for Research in Development Economics," Journal of Economic Perspectives, 24(3), 45-60.

Restuccia, D., D. T. Yang, and X. Zhu (2008): "Agriculture and Aggregate Productivity: A Quantitative Cross-Country Analysis," Journal of Monetary Economics, 55(2), 234-250.

Rodriguez, F., And D. Rodrik (2000): “Trade Policy and Economic Growth: A Skeptic's Guide to the Cross-National Evidence," NBER Macroeconomics Annual 2000, pp. 261-337.

Romer, P. M. (1986): "Increasing Returns and Long Run Growth," Journal of Political Eocnomy, 94, 1002-37.

_ (1990): "Endogenous Technical Change," Journal of Political Economy, 98, 71-102.

Sachs, J. D., And A. Warner (1995): "Economic Reform and the Process of Global Integration," Brookings Papers on Economic Activity, 1, 1-118. 
Schultz, T. W. (1953): The Economic Organization of Agriculture. McGrawHill, New York.

Schumpeter, J. A. (1942): Capitalism, Socialism and Democracy.

Song, Z., K. Storesletten, And F. Zilibotti (2011): "Growing Like China," American Economic Review, 101(1), 196-233.

Teignier-Baqu, M. (2009): "The Role of Trade in Structural Transformation," unpublished manuscript.

Unel, B. (2010): "Technology Diffusion through Trade with Heterogeneous Firms," Review of International Economics, 18, 465-481.

Varian, H. R. (2007): "An iPod Has Global Value. Ask the (Many) Countries That Make It.," New York Times, June 28, 2007.

Wacziarg, R., And K. H. Welch (2008): "Trade Liberalization and Growth: New Evidence," The World Bank Review, 22, 187-231.

Yi, K.-M., And J. Zhang (2011): "Structural Transformation in an Open Economy," Federal Reserve Bank of Minneapolis Staff Report No. 456.

Young, A. (2003): "Gold into Base Metals: Productivity Growth in the People's Republic of China During the Reform Period," Journal of Political Economy, 111(6), 1220-1261. 


\section{Appendix A}

\section{Appendix to Chapter 2}

\section{A.1 Representative Household Problem}

First we solve the representative household problem. The FOCs of household problem are as follows.

$$
\begin{aligned}
\frac{b}{c_{a t}-\bar{a}} & =\lambda_{t} p_{a t}, \\
\frac{1-b}{c_{m t}} & =\lambda_{t} p_{m t} .
\end{aligned}
$$

From the above two equations, we can obtain the ratio of consumption of two goods which is given by

$$
\frac{b}{1-b} \frac{c_{m t}}{c_{a t}-\bar{a}}=\frac{p_{a t}}{p_{m t}} .
$$

Combining the budget constraint for household in eqs. (2.3) and (2.4) we can 
obtain

$$
\begin{aligned}
c_{a t} & =\frac{b\left(w_{t} L+\pi_{t} H+r_{t} k_{t}\right)+(1-b) p_{a t} \bar{a}}{p_{a t}} \\
c_{m t} & =\frac{(1-b)\left(w_{t} L+\pi_{t} H+r_{t} k_{t}-p_{a t} \bar{a}\right)}{p_{m t}} .
\end{aligned}
$$

\section{A.2 Proof of Proposition 1}

In this subsection, I derive the allocation of labor in agricultural sector.

Since the wages for agricultural sector and final manufacturing good sector must be equal in equilibrium, we can obtain by eqs. 2.18) and 2.22

$$
p_{m t} A_{m t}(1-\sigma)(1-\alpha)\left(\frac{X_{t}}{k_{t}^{\alpha} l_{m t}^{1-\alpha}}\right)^{\sigma}\left(\frac{k_{t}}{l_{m t}}\right)^{\alpha}=\gamma p_{a t} A_{a t} l_{a t}^{\gamma-1} H^{1-\gamma}
$$

Notice also the demand for intermediate good is given by eq. 2.26) and plug into the above equation. We can obtain the following equation

$$
\left(\frac{X_{t}}{k_{t}^{\alpha} l_{m t}^{1-\alpha}}\right)^{\sigma}\left(\frac{k_{t}}{l_{m t}}\right)^{\alpha}=\frac{\gamma p_{a t} A_{a t} l_{a t}^{\gamma-1} H^{1-\gamma}}{p_{m t} A_{m t}(1-\sigma)(1-\alpha)}\left(\frac{l_{a t}}{H}\right)^{\gamma-1}
$$

Plug the eqs. 2.27) and 2.26 into the above equation, the equation becomes a equation with only one unknown $l_{a t}$ since $H$ is in fixed supply and can be seen as given. Then solving the equation gives the equation for labor allocation

$$
\left(l_{a t}\right)^{1-\gamma-\alpha}=\Omega\left(\frac{A_{a t}}{A_{m t}^{1 /(1-\sigma)}}\right)\left(\frac{p_{a t}}{p_{m t}}\right)\left(\frac{p_{i t}}{p_{m t}}\right)^{\frac{\sigma}{1-\sigma}}
$$


where the parameter $\Omega$ is defined as

$$
\Omega \equiv\left(\frac{1-\gamma}{\gamma} \frac{1-\alpha}{\alpha}\right)^{\alpha} \frac{\gamma}{(1-\alpha)(1-\sigma)}\left(\frac{1}{\sigma}\right)^{\frac{\sigma}{1-\sigma}}
$$

Hence the proposition follows. 


\section{Appendix B}

\section{Appendix to Chapter 3}

\section{B.1 Derivation of Aggregate Consumption}

In this appendix, we derive the aggregate consumption as shown in equation (19) .

First notice that the consumer's demand for $c_{t}$ is given by

$$
c_{t}(\omega)=\frac{C_{t}}{p_{t}(\omega) c_{t}(\omega)} .
$$

Plug in the pricing rule (7) and we can obtain

$$
c_{t}=\lambda^{S_{t}(\omega)} \frac{\varphi C_{t}}{\lambda w_{t}} .
$$


Plug into the definition of $C_{t}$ and we obtain

$$
\lambda w_{t}=\varphi \exp \left(\int_{0}^{1} \ln \left(\lambda^{S_{t}(\omega)}\right) d \omega\right)
$$

The labor used for production is given by

$$
l_{t}(\omega)=\frac{C_{t}}{\lambda w_{t}} .
$$

Hence we can obtain that

$$
C_{t}=\lambda w_{t} L_{t}
$$

From eqs. (B.2) and (B.4) we can obtain the aggregate consumption.

\section{B.2 Derivation of $(26)$}

First, we derive the equation (26) on the relationship between the two cutoff values of productivity. First plug the explicit expression of aggregate consumption $C_{t}$ which is given by (19) into (17). Then we can obtain

$$
f=\frac{1}{\rho+\Gamma M_{t}}\left(1-\frac{1}{\lambda}\right) \exp \left(\int_{0}^{1} \ln \left(\lambda^{S_{t}(\omega)}\right) d \omega\right) \frac{\varphi_{*}}{\lambda}\left(N+\frac{\rho}{\Gamma}\right) .
$$

Similarly, we can obtain another equation for $f_{x}$

$$
f_{x}=\frac{1}{\rho+\Gamma M_{t}}\left(1-\frac{\tau}{\lambda}\right) \exp \left(\int_{0}^{1} \ln \left(\lambda^{S_{t}(\omega)}\right) d \omega\right) \frac{\varphi_{x}}{\lambda}\left(N+\frac{\rho}{\Gamma}\right) .
$$


Divide (B.6) by (B.7) and we can obtain the equation (26) .

\section{B.3 Derivation of $(27)$}

Based on eq. (23), we can substitute (B.6) and (B.7) into eq. (23). Then we can obtain (27) . 